NBER WORKING PAPER SERIES

\title{
IS THERE A DIVERSIFICATION DISCOUNT IN FINANCIAL CONGLOMERATES?
}

\author{
Luc Laeven \\ Ross Levine \\ Working Paper 11499 \\ http://www.nber.org/papers/w11499
}

\author{
NATIONAL BUREAU OF ECONOMIC RESEARCH \\ 1050 Massachusetts Avenue \\ Cambridge, MA 02138 \\ June 2005
}

We would like to thank an anonymous referee, Raj Aggarwal, Luca Benzoni, Bernard Black, John Boyd, Mike Burkart, Stijn Claessens, Hans Degryse, Sonia Falconieri, Paul Healy, Harry Huizinga, S.P. Kothari, Xiaoji Lin, Vojislav Maksimovic, Hamid Mehran, Steven Ongena, Fabiana Penas, Henri Servaes, Raj Singh, David Smith, Ernst-Ludwig von Thadden, Andrew Winton, and seminar participants at the European Central Bank, HEC Lausanne, Stockholm School of Economics, Tilburg University, University of Mannheim, University of Minnesota, and the Conference on Agency Problems and Conflicts of Interest in Financial Intermediaries at the Dice Center for Research in Financial Economics of the Ohio State University for helpful comments and discussions, and Ying Lin for help with the data. This paper's findings, interpretations, and conclusions are entirely those of the authors and do not necessarily represent the views of the World Bank, its Executive Directors, or the countries they represent. The views expressed herein are those of the author(s) and do not necessarily reflect the views of the National Bureau of Economic Research.

(C2005 by Luc Laeven and Ross Levine. All rights reserved. Short sections of text, not to exceed two paragraphs, may be quoted without explicit permission provided that full credit, including $\odot$ notice, is given to the source. 
Is There a Diversification Discount in Financial Conglomerates?

Luc Laeven and Ross Levine

NBER Working Paper No. 11499

July 2005

JEL No. G2, G3, L2

\begin{abstract}
This paper investigates whether the diversity of activities conducted by financial institutions influences their market valuations. We find that there is a diversification discount: The market values financial conglomerates that engage in multiple activities, e.g., lending and non-lending financial services, lower than if those financial conglomerates were broken into financial intermediaries that specialize in the individual activities. While difficult to identify a single causal factor, the results are consistent with theories that stress intensified agency problems in financial conglomerates that engage in multiple activities and indicate that economies of scope are not sufficiently large to produce a diversification premium.
\end{abstract}

Luc Laeven

Economics Research

World Bank Group

1818 H Street NW

Washington, DC 20433

llaeven@worldbank.org

Ross Levine

Department of Economics

Brown University

64 Waterman Street

Providence, RI 02912

and NBER

rlevine@csom.umn.edu

(From August 1, 2005) 


\section{Introduction}

Theory provides conflicting predictions about the impact of greater diversity of activities on the performance of financial intermediaries. As suggested by the work of Diamond (1991), Rajan (1992), Saunders and Walter (1994), and Stein (2002), banks acquire information about clients during the process of making loans that may facilitate the efficient provision of other financial services, including the underwriting of securities. Similarly, securities and insurance underwriting, brokerage and mutual fund services, and other activities may produce information that improves loan making. Thus, financial conglomerates - banks that engage in a variety of activities - may enjoy economies of scope that boost performance and market valuations. ${ }^{1}$ Alternatively, diversification of activities within a single financial conglomerate may intensify agency problems between corporate insiders and small shareholders with adverse implications on the market’s valuation of the conglomerate. ${ }^{2}$ In particular, insiders may expand the range of financial activities if this diversification enhances the ability of insiders to extract private benefits from the financial institution. Thus, even if diversification of activities lowers the market's valuation of the financial conglomerate, insiders will still diversify if their extra private benefits exceed the losses that they incur from the drop in market valuation (Jensen, 1986; Jensen and Meckling, 1986). ${ }^{3}$

\footnotetext{
${ }^{1}$ Diversification within financial intermediaries can also boost market valuations by reducing the costs of providing incentives for delegated monitoring (Diamond, 1984). Financial conglomeration may also improve relationship lending and thereby improve the efficiency of financial intermediation (Petersen and Rajan, 1994). At a more general level, conglomerates might operate and coordinate distinct activities more efficiently than if those activities were operated as stand-alone firms (Chandler, 1977). Conglomerates may ease informational asymmetries and use internal capital markets to allocate resources efficiently, diversifying income flows and hence avoid inefficient bankruptcies, and exploit economies of scope (Williamson, 1970; Lewellen, 1971; Gertner, Scharfstein, and Stein, 1994). See Houston et al (1997) for evidence of the importance of internal capital markets in banking.

${ }^{2}$ Previous research indicates that conglomerates may make it more difficult to design efficient managerial incentive contracts and more difficult to align the incentives of outsiders with insiders (Aron, 1988; Stulz, 1990; Rotemberg and Saloner, 1994).

${ }^{3}$ In terms of U.S. banking regulations, the Gramm-Leach-Bliley Act of 1999 expanding the range of permitted bank activities partially reflects (i) a growing belief among policy makers about economies of scope in the provision of financial services and (ii) an amelioration of concerns about conflicts of interest and agency problems within financial conglomerates, which originally helped produce the Glass-Steagall Act of 1933. See Benston (1994) and Saunders and Walter (1994).
} 
Empirically, it is extraordinarily difficult to measure economies of scope in the provision of financial services or to measure agency problems in financial conglomerates. Berger and Humphrey (1994) argue that (1) there are severe econometric difficulties in identifying appropriate cost functions for financial conglomerates providing diverse services and (2) these difficulties help explain the profession's inability to confidently reject or accept the presence of economies of scope in financial activities. ${ }^{4}$ In related work on conflicts of interest in providing diverse financial services, an extensive literature examines the impact on the price of a firm's securities of a bank that both makes loans to the firm and sells its securities (e.g., Kroszner and Rajan, 1994; Puri, 1996; Gande et al. 1997, 1999; and Schenone 2004). ${ }^{5}$ This work tests whether banks that make loans to a firm and underwrite its securities sell securities to the public at inflated prices to subsidize their lending operations. Recent evidence from the United States finds the opposite: Financial conglomerates that combine lending and investment banking activities tend to charge lower fees (Sufi, 2004; and Drucker and Puri, 2005). This research, however, does not study whether engaging in diverse activities intensifies agency problems between financial institution insiders and outsiders with adverse ramifications on the market's valuation of financial conglomerates. Thus, while diversification may provide cost savings to some clients, diversification of activities might still enhance the ability of insiders to expropriate financial institution resources for private gain and thereby lower the conglomerate's market value.

Rather than attempting to measure economies of scope and agency problems directly, we investigate whether the diversity of activities conducted by financial institutions - "banks" -

\footnotetext{
${ }^{4}$ For example, the bulk of research provides little evidence of large economies of scope (e.g., Berger, Hanweck, Humphrey, 1987; Berger and Humphrey, 1991; Ferrier et al, 1993; and Pulley and Humphrey, 1993). In Europe, Vander Vennet (2002) finds that universal banks are more cost and profit efficient than specialized banks, but Allen and Rai (1996) find little evidence for complementarities between lending and investment-related services. There is a large, distinct literature on scale economies in banking (Berger, Demsetz, and Strahan, 1999).

${ }^{5}$ Also, see Ber, Yafeh, and Yosha (2001), and Benzoni and Schenone (2005).
} 
influences their market valuations. More specifically, we examine whether the Tobin's $q$ of a financial conglomerate is more or less than the $q$ it would have if the conglomerate were broken into a portfolio of banks that each specializes in the individual activities of the conglomerate.

Diversification of activities within a single financial conglomerate may yield economies of scope that boost valuations. Or, diversity of activities may intensify agency problems and induce a diversification discount in the valuation of financial conglomerates. We examine the net impact of positive and negative effects of diversification on valuation. As explained below, we use numerous econometric procedures to control for simultaneity bias and identify the independent impact, if any, of diversity on the valuation of financial conglomerates.

This paper focuses on diversity per se. Thus, we control for the possibility that the market values different financial activities differently. For example, if securities underwriting is valued more highly than loan making, then a bank that does both may have a higher $q$ than a bank that only makes loans. We abstract from these activity-effects on valuation to identify the independent impact of diversity on valuations by using a modified version of the Lang and Stulz (1994) and LeBaron and Speidell’s (1987) ‘chop-shop’ method. Specifically, we compare the q’s of diversified banks to the estimates of the q's these banks would have if they were decomposed into a bank specialized in loan-making activities and a bank specialized in non-lending activities. Using data on 836 banks, across 43 countries, over the period 1998-2002, we examine the impact of diversity on the valuation of financial conglomerates.

Our research builds on the non-financial corporate diversification literature, which identifies key methodological hurdles associated with assessing whether diversification affects stock market valuations. Lang and Stulz (1994), Berger and Ofek (1995), and Servaes (1996) find a diversification discount: The Tobin's $q$ of diversified firms is less than the $q$ 's they would have if 
separated into portfolios of specialized firms. ${ }^{6}$ Using plant-level data from U.S. manufacturing firms, however, Maksimovic and Phillips (2002) find that less productive firms tend to diversify, but diversity does not cause lower productivity. Campa and Kedia (2002) find that the same traits that induce firms to diversify also lower firm values. They conclude that researchers have wrongly attributed the diversification discount to diversification per se rather than to the firm's underlying characteristics. $^{7}$ Graham, Lemmon, and Wolf (2002) argue that conglomerates tend to purchase already discounted target firms, which produces the diversification discount. Thus, they too argue that there is no evidence that diversification intensifies agency problems and destroys value. Finally, Villalonga (2004a) argues that data problems are driving the entire corporate diversification literature. She identifies flaws with the industrial segment data from Compustat due to the fact that firms self-report their activities and shows that this self-reporting biases the results toward finding a diversification discount. ${ }^{8}$ Thus, a proper examination of the impact of diversification must account for simultaneity bias, mergers and acquisitions (M\&As), and problems associated with self-reported activity data.

Besides controlling for endogeneity and M\&As, this paper contributes to the broader diversification literature by (i) examining diversity within one industry - the financial services industry - rather than examining diversity across broad industrial activities and (ii) by reducing potential biases associated with the common use of self-reported activity data. Instead of examining the valuation effects of diversification across very distinct businesses, e.g., an oil company

\footnotetext{
${ }^{6}$ Also, see Morck, Shleifer, and Vishny (1990), Comment and Jarrell (1995), John and Ofek (1995), Lins and Servaes (1999), Rajan, Servaes, and Zingales (2000), and Schoar (2002). Denis, Denis, and Sarin (1997) find that agency problems drive the corporate diversification decisions.

${ }^{7}$ Other work that emphasizes the endogeneity of the diversification decision includes Fluck and Lynch (1999), Chevalier (2000), Lamont and Polk (2001), Whited (2001), and Villalonga (2004b).

${ }^{8}$ In particular, Villalonga (2004a) notes serious problems with comparability across firms since each firm chooses how to aggregate specific activities into the broad segments in Compustat. Indeed, 25 percent of changes in firms' number of segments over time are due purely to reporting changes, not real changes in diversification. Using data at the establishment level, Villalonga (2004a) finds a diversification premium.
} 
diversifying into food processing, we focus on diversification in an industry where economies of scope are likely to be pronounced: the provision of information intensive financial services. ${ }^{9}$ Evidence of a diversification discount, therefore, would provide particularly compelling (though not conclusive) evidence of agency problems associated with financial conglomeration. We use data that is not biased toward indicating a diversification discount. In particular, our modified chop-shop approach does not rely on self-reported information on whether a firm participated in an activity or not. Rather, we directly measure the extent to which each financial conglomerate participates in each activity.

There are, however, special complexities associated with assessing whether diversification of bank activities increases or decreases bank valuations. First, deposit insurance creates an incentive problem that is not found outside of deposit-taking banks. Namely, diversification could be good for valuations if diversification allows owners to exploit the deposit insurance guarantee (Boyd, Chang, and Smith, 1998). We attempt to control for this by combining information on (i) the generosity of government-sponsored deposit insurance and (ii) each bank's ratio of deposits to total liabilities. Second, governments typically heavily regulate or own banks. Thus, besides using country-fixed effects in most specifications, we control for cross-country differences in bank regulatory and supervisory policies and the degree of government ownership of banks. Indeed, the potential "specialness" of banks motivates this study of diversity. A third complexity with examining financial conglomerate diversity is the difficulty associated with measuring distinct financial activities. Due to data constraints, we primarily differentiate banks by (i) interest income

\footnotetext{
${ }^{9}$ Some research finds that financial intermediaries are more opaque than non-financial corporations, so that financial conglomerates may be much more difficult to monitor than industrial conglomerates or specialized financial intermediaries. Thus, agency problems may be comparatively severe in opaque financial conglomerates. Morgan (2002) finds that bond analysts have greater dispersion of bond ratings for banks as compared to non-financial corporations, which he interprets as suggesting greater opaqueness of banks. Flannery, Kwan, and Nimalendran (2002), however, do not confirm this finding using stock analysts reports, while Adams and Mehran (2003) argue that the boards of directors of banks may find it easier to monitor banks as compared to manufacturing firms because bank boards also have access to the reports of bank regulators.
} 
versus non-interest income and by (ii) loans versus other earning assets. Thus, we generally do not distinguish among securities underwriting, brokerage services, insurance underwriting, etc. We simply differentiate banks by lending versus non-lending activities. This is a problem of precision and could therefore produce insignificant results. We do not believe, however, that this biases the results toward finding a diversification premium or discount. Furthermore, in robustness tests, we (i) expand the analyses to include insurance companies and insurance activities and (ii) confirm that our measures are highly correlated with diversity measures from different data sources.

We find a diversification discount. The market values banks that engage in multiple activities much lower than if those banks were broken-up into financial intermediaries that specialize in the individual activities. The results are "consistent" with the view that diversification intensifies agency problems in financial conglomerates with adverse implications on market valuations and these "costs" to diversification outweigh any benefits accruing from economies of scope. Nevertheless, although we conduct an array of robustness checks to sharpen the interpretation of the findings, we do not directly measure agency problems. Thus, we cannot unequivocally conclude that intensified agency problems in financial conglomerates drive the results. We can more confidently argue that economies of scope are not sufficiently large to produce a diversification premium.

The results are robust to controlling for simultaneity bias and some non-agency cost explanations of the diversification discount. As a preliminary test of whether bank-specific traits influence both the value of the bank and its decision to diversify, we simply control for many bankspecific characteristics directly in the valuation regressions and then use bank-fixed effects in other specifications. Next, we use different sets of instrumental variables to extract the exogenous component of bank diversity in assessing the influence of diversity on valuations. Third, we use a 
Heckman (1979) self-selection model to control for potential biases induced by banks choosing to diversify. Finally, we control for major bank mergers and acquisitions (M\&A) since specialized institutions may be inappropriate benchmarks for valuing target institutions in acquisitions or for valuing mergers (Graham, Lemmon, and Wolf, 2002). When using these different statistical methods to account for potential simultaneity bias, self-selection bias, and biases induced by including M\&As, we continue to find a diversification discount.

The diversification discount in financial conglomerates holds after conducting a battery of additional robustness checks and controlling for additional possible explanations of the discount. We (i) use different indicators of bank diversity, (ii) employ a variety of methods to control for the valuation of different activities to identify the pure diversity effect, (iii) analyze the impact of diversity on operating income as an alternative indicator of bank performance (instead of market valuation), (iv) assess whether diversification simply involves banks that are comparatively inefficient at loan-making diversifying into investment banking (and vice-versa), (v) test different sub-samples of countries (with a particular focus on the United States) and years, and (vi) condition on country-specific characteristics, including economic growth, inflation, and the size of the market, that may influence valuations. Throughout, we find a negative relationship between diversification and bank valuations.

The paper proceeds as follows. Section 2 describes the data. Section 3 presents the core results. Extensions and robustness tests are presented in section 4. Section 5 concludes. 


\section{Data and Variables}

\section{$\underline{\text { A. Sample of Banks }}$}

Bank-level data come from Bankscope, which contains financial information on banks around the world and which contains considerably more data on financial firms than alternative data sources. ${ }^{10}$ To enhance comparability across countries, we exclude small banks, defined as banks with less than US\$ 100 million in total assets. Furthermore, we exclude "banks” that are neither engaged in investment banking nor in deposit-taking and loan-making. In extensions presented below, we explicitly consider insurance companies and insurance activities. Also, we eliminate banks classified as Islamic banks because the accounting information does not match with the rest of the sample. We also exclude banks with missing data on basic accounting variables, including assets, loans, deposits, equity, interest income and non-interest income. ${ }^{11}$ Finally, we exclude extreme outliers, which we define as banks where the basic accounting variables are more than four standard deviations from the sample mean. ${ }^{12}$

For the 43 countries with banks in our sample, all the countries allow banks to engage in some investment banking and other non-lending activities, though to differing degrees (see Barth et al., 2004). The variability in regulatory restrictions is not crucial for our analyses. The crucial issue is that banks engage in a spectrum of activities, ranging from purely lending to purely non-lending activities. In robustness tests that we present below, we find that this paper's results hold when using an index of regulatory restrictions on bank activities as an instrument for our measures of bank diversity. We use the last five years for which Bankscope has data, 1998-2002. The final

\footnotetext{
${ }^{10}$ Below, we show that (i) our measures of financial intermediary activities are highly correlated with those from alternative datasets (e.g., Worldscope) but (ii) Bankscope has information about many more financial institutions than these alternative datasets. Bankscope is maintained by Bureau Van Dijk.

11 This reduces the sample by 232 bank-year observations.

12 This excludes only 43 bank-year observations. The results hold when we include these observations and winsorize the data.
} 
dataset includes 3,415 bank-year observations (with a maximum of 836 observations for the year 2002). ${ }^{13}$

\section{B. Bank-Level Measures of Activities and Diversity}

Ideally, we would like detailed data on the degree to which each bank underwrites securities, provides brokerage services, operates mutual funds, securitizes assets, underwrites insurance, etc. Data availability, however, restricts our ability to measure the diversity of bank activities. Also, for most countries there is no information available on fee income on loans or a breakdown of interest income by asset category (loans versus other interest earning assets). Moreover, banks in the vast majority of countries only report net fee income, not gross fee income.

Given these data constraints, the remainder of this subsection describes the core data on bank activities and diversity. We divide the discussion into three parts.

First, we construct asset-based and income-based measures of the extent to which banks engage in loan making activities or fee/trading-based activities. As a caricature, we can think of specialized - or "pure" - commercial banks as converting deposits into loans. To continue the caricature, we can think of specialized investment banks as underwriting securities but not making loans. Of course, financial conglomerates provide a broad array of financial services; they make loans, underwrite securities, underwrite insurance policies, securitize assets, and sell a wide-array of financial services. Due to data limitations, we focus on the distinction between interest generating activities and fee generating activities. In robustness tests reported below, we distinguish insurance activities from the provision of other financial services.

\footnotetext{
${ }^{13}$ The 43 countries included in our sample are: Argentina, Australia, Austria, Belgium, Brazil, Canada, Chile, Colombia, Denmark, Egypt, Finland, France, Germany, Greece, Hong Kong (China), India, Indonesia, Ireland, Israel, Italy, Japan, Jordan, Kenya, Rep. of Korea, Malaysia, Mexico, Netherlands, Norway, Pakistan, Peru, Philippines, Portugal, Singapore, South Africa, Spain, Sweden, Switzerland, Taiwan, Thailand, Turkey, United Kingdom, United States, and Venezuela.
} 
Second, we construct asset-based and income-based measures of diversity. That is, we measure the degree to which banks specialize in lending or non-lending services, or whether they perform a diversity of activities. Lower values of these diversity indexes imply more specialization, while higher values signify that the bank engages in a mixture of lending and non-lending activities. Clearly there is a link between these diversity measures and the measures of the degree to which banks engage in loan making or non-loan making activities. If a bank only makes loans, it will be classified as having zero diversity. The two measures, however, also capture different traits. The diversity indexes measure diversity per se, while the activity measures gauge where each bank falls along the spectrum from a pure lending bank to a pure fee-generating bank. Since we are primarily concerned with the impact of diversity per se on valuations, we focus on the diversity measures.

Third, this subsection summarizes the data and discusses whether these activity and diversity measures accurately characterize individual banks. Given the difficult in measuring the degree of financial conglomeration, it is important to assess whether our measures accurately characterize individual financial institutions.

\section{B.1. Measures of Activities}

To measure where along the spectrum each bank falls from pure commercial banking to specialized investment banking, we first construct an asset-based measure that equals loans relative to total earning assets. Total-earning assets include loans, securities, and investments. Very high values signal that the bank specializes in loan making, like the specialized commercial banks mentioned above. Though with potential measurement error, very low values of these ratios signal 
that the bank is not specialized in loan making and indicates the financial institution specializes in non-loan making activities. ${ }^{14}$

The second measure of where each bank falls along the continuum from pure lending to pure fee/trading-based activities is an income-based indicator that equals the ratio of net interest incometo-total operating income. Total operating income includes net interest income, net fee income, net trading income, and net commission income. In terms of assessing where along the spectrum each bank falls, a specialized loan-making bank will have a larger ratio of net interest income-to-total operating income, while a specialized investment bank is expected to have a larger share of other operating income (fees, commissions, and trading income).

The asset-based measure suffers from fewer measurement problems than the income-based measure, but we include both for robustness. In particular, since loans may yield fee income, the income-based measure may overestimate the degree to which some lending institutions engage in non-lending activities. Also, we would prefer to use gross rather than net income to measure bank activities, but as noted above, we simply do not have gross income for many banks. To use the income-based measure as a robustness check, however, we simply require that there is a positive correlation between the extent to which banks engage in a particular activity and the net income generated from that activity. Thus, while presenting both sets of results, we place greater weight on the analyses using the asset-based measure.

\footnotetext{
${ }^{14}$ In some countries, banks are forced by the government to invest in government securities. In robustness tests discussed below, we control for cross-country differences in reserve requirements and government ownership of the banking industry.
} 


\section{B.2. Measures of Diversity}

Next, we construct two measures that focus on diversity per se.

Asset diversity is a measure of diversification across different types of assets and is

calculated as $1-\left|\frac{(\text { Net loans - Other earning assets })}{\text { Total earning assets }}\right|$, where Other earning assets include securities and investments. Total earning assets is the sum of Net loans and Other earning assets, and |.| denotes the absolute value indicator. Asset diversity takes values between 0 and 1 and is increasing in the degree of diversification.

Income diversity is a measure of diversification across different sources of income and is calculated as $1-\left|\frac{(\text { Net interest income-Other operating income })}{\text { Total operating income }}\right|$. Net interest income is interest income minus interest expense and Other operating income includes net fee income, net commission income, and net trading income. Income diversity takes values between 0 and 1 and is increasing in the degree of diversification. Note, the asset diversity and income diversity measures are "complementary" in that asset diversity is based on stock variables, and income diversity is based on flow variables.

For robustness, we compute and analyze alternative diversity measures. These alternatives (i) combine information on both asset and income diversity and (ii) use various discrete thresholds of diversity, rather than the continuous 0 to 1 variable just described. These yield similar results and we discuss them further in the robustness section of the paper.

\section{B.3. Summary Statistics and Discussions of Individual Banks}

Before describing how we adjust for differences in bank activities in valuing banks, we provide summary statistics on bank activities and analyze whether our measures of asset and 
income diversity accurately reflect the activities of individual banks. Table 1 offers summary statistics of the main variables. Averaging across all bank-year observations, the average Net interest income to total operating income is 66 percent. The sample variation is substantial as indicated by the standard deviation of 20 percent. The figures for the Loans to total earning assets ratio are similar with an average of 66 percent and a standard deviation of 18 percent. The average income diversity is 0.54 and the average asset diversity is 0.58 . Again, the variation is substantial, with some banks having income or asset diversity scores close to one (i.e., perfect diversification between lending and non-lending activities). Note that all four measures take values between 0 and 1. These summary statistics are virtually identical when we examine only one year from the sample.

The asset and income measures of where banks fall along the spectrum from pure lending banks to pure fee/trade generating banks are not perfectly correlated. The correlation between the net interest income to total operating income and the loans to total earnings asset ratio is 52 percent. This suggests that the two indicators measure different aspects of bank activities. As explained above, there are greater measurement problems with the income-based measure, which may help explain the relatively low correlation between the asset-based and income-based measures.

To assess whether these gross measures of bank activities and diversity accurately characterize individual institutions, we now examine a few banks in detail. In particular, we first use our database to identify individual banks that are classified as specialized commercial banks, specialized investment banks, or financial conglomerates and then use company websites and industry publications to obtain more specific information on each bank. To facilitate comparisons, we consider data at the mid-point of the sample period, i.e., the year 2000.

The income-based measure of bank activities does a good job of distinguishing specialized investment banks from banks focusing on lending. For example, Net interest income-to-total 
operating income ranges from 1.6 percent for Okasan Holdings in Japan to 98.3 percent for Hudson City Bancorp in the United States. Okasan Holdings is a major securities house with Okasan securities the Group's core enterprise. Expanding beyond this one case, other securities houses like Daewoo Securities in Korea and Tokai Tokyo Securities in Japan have net interest income-to-total operating income of less than 3 percent. Well-known U.S. investment banks Goldman Sachs (5.9 percent) and Lehman Brothers (8.4 percent) also have a net interest income-to-total operating income ratio of less than 10 percent. At the other extreme, the income-based measures also identify "pure” loan making banks. Hudson City Bancorp, with a net interest income-to-total operating income ratio of 98.3 percent, is the holding company for Hudson City Savings Bank, a thrift that operates approximately 80 branches in more than a dozen counties in New Jersey and focuses on consumer lending as opposed to investment banking. Other banks with a net interest income-toptotal operating income ratio of more than 90 percent include Daito Bank in Japan, IKB Deutsche Industriebank in Germany, and State Bancorp and First Sentinel Bancorp in the United States, all of which are commercial banks with business strategies focused on lending operations. ${ }^{15}$

The asset-based measures of bank activities also pass the "smell test" by accurately categorizing individual financial institutions. Loans-to-total earning assets ranges from 0.0 percent for OZ Holdings in Switzerland to 98.3 percent for Paragon Group in the United Kingdom. OZ Holdings is a specialized investment-banking group in Switzerland, with OZ Bankers the core enterprise. According to its website, its business philosophy focuses on the Swiss equity and options markets. Other financial intermediaries with a loans-to-earnings assets ratio of less than 10 percent include Daiwa Securities of Japan and Daewoo Securities of Korea, banks that both focus on the

\footnotetext{
${ }^{15}$ In total, 44 banks have a net interest income-to-total operating income ratio of more than 90 percent. In contrast, 22 financial intermediaries have a net interest income-to-total operating income ratio of less than 10 percent.
} 
securities underwriting business. ${ }^{16}$ At the other end of the spectrum, Paragon Group is a publicly listed provider of consumer finance, providing personal loans, retail loans, mortgage loans, and car loans. Other banks with a loans-to-earnings assets ratio of more than 90 percent include Banco de Andalucia in Spain, Neue Aargauer Bank in Switzerland, and Republic Bancorp and Household International in the United States, all of which have business strategies that emphasize lending, with minimal or no investment banking activities.

Next, we consider highly diversified banks, i.e., banks classified as engaging in a diverse set of lending and fee/income generating activities. A number of banks have loan-to-total earning assets ratios or loans to total earning asset ratios of very close to 50\% (between 49 and 51\%), including HSBC Holdings, Citigroup, and ABN Amro Bank. Again, a detailed review of these financial conglomerates verifies that these banks engage in both commercial banking and investment banking activities, including asset management. In sum, our measures of (1) bank activities and (2) bank diversity do a reasonably good job in characterizing individual banks.

\section{Bank-Level Performance: Tobin's q, Activity-Adjusted q, and Excess Value}

Tobin's $q$ : We use Tobin’s $q$ as a measure of bank valuation. Tobin’s $q$ is calculated as the sum of the market value of common equity plus the book value of preferred shares plus the book value of total debt divided by the book value of total assets. As noted by Lang and Stulz (1994), $q$ is designed to measure the present value of future cash flows divided by the replacement cost of tangible assets. Thus, one of the advantages of using $q$ is that there is no theoretical reason to adjust for risk or leverage to compare firms. Nevertheless, two concerns are frequently expressed about

\footnotetext{
${ }^{16}$ Goldman Sachs and Lehman Brothers have a loans-to-earnings assets ratio of 10.9 percent and 13.2 percent respectively. In total, 11 financial intermediaries have a loans-to-earnings assets ratio of less than 10 percent, while 28 banks have a net loans-to-earnings assets ratio of more than 90 percent.
} 
using $q$ to measure bank performance. First, banks are extremely highly leveraged. Second, banks' tangible assets are primarily financial assets, so market values and replacement costs are identical for most assets (Brook et al. 1998). For robustness, therefore, we reassess - and confirm - the results using a simple performance measure: the ratio of operating income to total assets.

Activity-adjusted q: Since different banking activities may be valued differently, it is important to control for the degree to which banks engage in different activities when comparing their valuations. For example, if investment banking is valued differently from commercial banking, one needs to control for the extent to which the bank is engaged in either activity in order to isolate the relationship between valuation and diversity per se. Thus, we compute excess values following a modified version of the "chop-shop" approach introduced by LeBaron and Speidell (1987) and Lang and Stulz (1994). The idea is to compare the Tobin's $q$ of each bank with the $q$ that would exist if the bank were "chopped" into separate financial "shops" (pure-activity banks) that each specializes in a financial activity (e.g., lending or fee/income generation).

Activity-adjusted $q_{j}$ is our estimate of the $q$ that would prevail if bank $j$ were divided into activity-specific financial institutions and then priced according to the q's associated with each of those activity-specific activities. At a general level, consider bank $j$ that engages in $n$ activities. Let $\alpha_{j i}$ equal the share of the ith activity in the total activity of bank $j$, so that $\sum_{i=1}^{n} \alpha_{j i}=1$. Let $q^{\mathrm{i}}$ equal the Tobin's $q$ of financial institutions that specialize in activity i (pure-activity $q$ ). Then, Activity adjusted $q_{j}=\sum_{i=1}^{n} \alpha_{j i} q^{i}$

More specifically, we primarily consider two banking activities: lending operations versus non-lending operations, including trading, investments, and advisory services. From an asset perspective, we focus on the distinction between investments in loans and investments in securities 
or other companies. From an income perspective, we focus on the distinction between interest income (mainly from loans) and non-interest income, including fees, commissions, and trading income. For simplicity, we refer in what follows to the first activity as "commercial banking” and to the second as "investment banking". Thus, $q^{1}$ is the valuation of an activity-specific bank focused on commercial banking, while $q^{2}$ is the valuation of an activity-specific bank focused on investment banking. With two activities, the definition of activity-adjusted $q$ for bank $j$ simplifies to the following:

$$
\text { Activity adjusted } q_{j}=\left(\alpha_{j 1} q^{1}+\alpha_{j 2} q^{2}\right)=\left(\alpha_{j 1} q^{1}+\left(1-\alpha_{j 1}\right) q^{2}\right)
$$

In what follows, we compute two activity-adjusted $q$ measures. That is, we calculate activityadjusted $q$ based on both the asset and income measures of the share of bank activity. Thus, $\alpha_{j 1}$ equals either the ratio of net interest income to total operating income or the ratio of net loans to earnings assets for bank $j$.

Excess value: equals the difference between a bank’s actual q and the activity-adjusted $q$, so that the excess value for bank $j$ is

$$
\text { Excess value }_{j}=q-\left(\alpha_{j 1} q^{1}+\alpha_{j 2} q^{2}\right)=q-\left(\alpha_{j 1} q^{1}+\left(1-\alpha_{j 1}\right) q^{2}\right)
$$

Again, we compute two measures of excess value, one based on weights determined by the asset composition of the bank and the other determined by the income composition of the bank.

To measure activity-adjusted $q$ 's and compute excess value, we construct $q^{1}$ and $q^{2}$ (pureactivity q’s) from banks that specialize in one activity. We follow the literature in defining what constitutes specialization. For asset-based measures, banks where $90 \%$ of the assets are associated with one activity are classified as specialized. In this case, $q^{1}$ is the average $q$ of banks with a ratio of net loans to earnings assets of more than 0.9. Similarly, for income-based measures, specialized banks receive $90 \%$ of their income from one activity, so that $q^{1}$ equals the average $q$ of banks with a 
ratio of net interest income to total operating income of more than 0.9 . These pure-activity q's are calculated by averaging across banks from different countries. Most countries do not have a sufficiently large number of pure-activity banks to estimate pure-activity q's at the country-level. In many of the regression analyses below, we use country fixed effects and year dummy variables to control for differences in $q$ across countries and years. Moreover, instead of averaging across all specialized banks, we confirm this paper's results when using only U.S. banks to estimate pureactivity q's. Furthermore, as discussed below, the results hold when using alternative definitions of pure-activity banks, when only examining U.S. banks, and when excluding U.S. banks from the analyses.

In constructing activity-adjusted $q$ 's and excess values, we need to compute $\alpha_{j 1}$ and $\alpha_{j 2}$, which are the shares of pure commercial banking and investment banking in bank $j$ 's activities. The eights are based on the relative importance of interest income to total operating income in the case of the income diversity measure. In case of the asset diversity measure, the weights are based on the relative importance of loans to total earning assets.

\section{Alternative Data Sources: Worldscope and Compustat}

Although we considered alternative data sources to measure bank diversity, there are important advantages to using Bankscope. One alternative data source is Worldscope. For instance, Lins and Servaes (1999) use data from Worldscope to examine the diversification discount in nonfinancial corporations. At the two-digit SIC code level, Worldscope has data on bank activities (e.g., SIC 60: Depository institutions, SIC 61: Nondepository credit institutions, and SIC 62: Security, commodity brokers, and services). These data, however, are self-reported by banks and are therefore subject to the Villalonga (2004a,b) biases that we discussed above. Furthermore, there 
is not a clear match between reporting that an institution participates in an activity and the extent of this participation (i.e., Worldscope does not have segment data for most banks). That is, we cannot confidently assign a percentage of bank income or assets to a particular SIC code activity, so we cannot use the two-digit SIC code data to compute comparable diversity measures to the ones that we have. Furthermore, we only have data from Worldscope on $62 \%$ of the observations in our sample. Nevertheless, we used Worldscope to classify banks as either lending institutions (SIC 60 or 61) or investment banks (SIC 62), where we only use the 1334 observations on specialized banks that report operating in only one of these two categories. We find a very strong correlation between the Worldscope data and the Bankscope measures of bank activities. Specifically, the correlations between Lending institutions (from Worldscope) and both Loans/Earning assets and Interest Income/Operation income (from Bankscope) are about 0.6 and significant at the one percent level. The correlations are similar for Investment banks. Thus, our measures of bank activities correspond closely to the self-reported information available from Worldscope. Given the problems and limitations associated with the Worldscope data on financial institutions, we use the Bankscope data.

Another alternative data source is Compustat. Although much of the literature on corporate diversification examines U.S. corporations with Compustat data, it is not possible to follow this literature and focus only on financial institutions. Besides the problems associated with using Compustat data discussed above, Compustat has (segment) data on only 18 of the 362 U.S. banks in our sample. Furthermore, most of these banks do not report income and asset data by activity. Given all these limitations, we cannot apply the Lang and Stulz (1994) chop-shop approach to U.S. banks based on Compustat data. Thus, we develop a new approach that does not rely on self-reported 
segment data but instead directly computes the degree of diversity based on income and asset data in Bankscope.

\section{Empirical Results}

\section{$\underline{\text { A. The Excess Value of Diversified Banks: Initial Results }}$}

The first two rows of Table 2 show the mean and median excess values of diversified banks. We report excess values for diversified banks measured by both (i) income diversity and (ii) asset diversity. Again, a bank is defined as diversified if the ratio of interest income to total operating income is between 0.1 and 0.9 or if the ratio of loans to total earning assets is between 0.1 and 0.9 .

Diversified banks have large negative excess values, which are significant at the one percent level. The excess values for diversified banks are about -0.06 (or 6\% of average $q$ ) using either the income or asset measure of bank diversity and when using either means or medians. This indicates a diversification discount. Besides comparing the discount to average $q$, we can also compare the discount to the variability of $q$, which indicates that the diversification discount is about 38 percent of the standard deviation of $q$. The diversification discount as a percentage of average $q$ is smaller than those obtained by Lang and Stulz (1994) for non-financial corporations, 6\% relative to 32\%. This is consistent with findings by Berger and Ofek (1995) who find that (i) industry diversification reduces value on average, but (ii) relatedness mitigates the value loss from diversification. In other words, it matters whether one considers diversification into completely different industries or into closely related industries (for example, within the same 2-digit SIC code industry). Diversification into closely related activities, such as within the financial services industry, produces a smaller discount. $^{17}$

\footnotetext{
${ }^{17}$ Part of the difference between the discount in corporations and banks is explained by differences in the denominator: the $\mathrm{q}$ of non-financial corporations is higher than the average value of q in our sample of financial institutions (1.11
} 
The third row in Table 2 confirms that diversified banks have negative excess values using a different approach. Rather than computing means and medians of excess values, the third row presents the estimated coefficient and t-statistic on the diversification dummy variable from a regression of Tobin's $q$ on constant, country dummy variables, year dummy variables, and a diversification dummy variable. We label this row, “unadjusted excess value,” because we do not directly adjust bank valuation by each bank's mix of activities, i.e., we do not use excess value as the dependent variable. The results show that on average the $q$ of a diversified bank is lower than the $q$ of specialized banks (as defined by either the income or asset diversification dummy variable respectively) after controlling for country and year effects.

\section{B. The Excess Value of Diversified Banks: Regression Results}

The objective is to assess the relationship between diversity per se and bank valuation while abstracting from the possibility that the market values different financial activities differently and that banks engage in distinct mixes of financial activities. In other words, it is important to control for the possibility that banks with a large share of non-interest income may be valued differently from banks that obtain revenues predominantly from interest. The standard way to do this is to use the chop-shop approach and compute excess values. While Tobin's q incorporates both the market's valuation of (i) diversity and (ii) each bank's set of activities, excess value controls for the market's valuation of different bank activities by subtracting activity-adjusted $q$ from Tobin's $q$ and therefore provides a more direct way for assessing the impact of diversity per se on the market's valuation of the bank.

compared to 1.06). Also, when comparing the discount to the standard deviation of q, the discount in Lang and Stulz (1994)'s examination of non-financial corporations is 29 percent of the standard deviation of corporate q's (0.35/1.22), while we find that the discount in banks is 38 percent of bank q's. 
Columns (1) and (2) of Table 3 report the results from regressing excess value on the income diversity and asset diversity measures respectively. Since we are pooling data across countries and over time, the regressions also include country and year dummy variables. Furthermore, it is inappropriate to assume that bank observations over time are independent. Consequently, the standard errors are adjusted for clustering at the bank-level.

We find that both income diversity and asset diversity are negatively linked to excess value. After controlling for country and time effects and after controlling for differences in the valuation of different bank activities, there is a diversification discount in financial conglomerates. The relationship is economically meaningful. For example, a one-standard deviation increase in asset diversity reduces excess value by almost 0.03 . This is not inconsequential, when considering that the mean value of excess $q$ is -0.06 with a standard deviation of 0.17 .

Table 3 also assesses whether there is a diversification discount in financial conglomerates by examining Tobin's $q$ instead of excess value. Recall that in regressions (1) and (2), the dependent variable is excess value, which equals Tobin's $q$ minus activity-adjusted $q$. In regressions (3) and (4), the dependent variable is Tobin's $q$. To control for the fact that banks engage in different mixes of financial activities, regressions (3) and (4) control for these differences by including a measure of the mixture of each bank's activities as a regressor. Thus, when examining income diversity, we regress Tobin's $q$ on income diversity and net interest income to total operating income (regression 3). Regression (4) is very similar, except that it examines asset diversity and controls for loans to total earning assets. In these regressions, we also include country and year dummy variables and adjust the standard errors for clustering at the bank level.

The Table 3 results on Tobin's $q$ confirm the earlier results: There is a diversification discount in financial conglomerates. We find a negative association between the diversity of bank 
activities and the market's valuation of the bank while controlling for differences in the mixture of bank activities. The results also indicate that banks that engage in less traditional activities - such as activities that generate non-interest income and activities that require investments in assets other than loans - are generally valued more highly than banks more specialized in loan making. Since income and asset diversity remain negatively associated with bank valuations when controlling for net interest income to total operating income and loans to total earnings respectively, the findings suggests that it is specialization per se that is linked with lower bank valuations.

\section{The Excess Value of Diversified Banks: Bank-Level and Country-Level Controls}

In Table 4, we investigate the robustness of the diversification discount in financial conglomerates to controlling for bank-level and country-level characteristics. Table 4 has two panels. Panel A presents regression results that focus on income diversity and Panel B presents results that focus on asset diversity. In both panels, the first four columns present results where the dependent variable is excess value, which is the standard measure for assessing the diversification discount. The last four columns in each panel present results where the dependent variable is Tobin's q. When the dependent variable is Tobin's q, we include both the diversity measure (Income diversity in Panel A and Asset diversity in Panel B) and an activity measure (Net interest income to total operating income in Panel A and Loans to total earning assets in Panel B). We include the activity measure to control for the mixture of activities conducted by each bank and to therefore identify the relationship between valuation and diversity per se. In Table 4, besides controlling for specific bank-level traits and controlling for time-varying country characteristics, we also use country and year fixed-effects. 
In terms of bank-level controls, we control for numerous bank-level traits in Table 4 and continue to find a negative, significant relationship between measures of the diversity of bank activities and the market's valuation of the bank. First, size is often thought to affect valuation and performance through economies of scale. As in Lang and Stulz (1994), we therefore control for the logarithm of total assets. Furthermore, we also include the logarithm of total operating income as an alternative measure of bank size. Total operating income may better capture the importance of a bank's off-balance sheet items. While the logarithm of total operating income enters the valuation regressions positively and significantly, we continue to find that diversity is associated with lower valuation. Second, we include the ratio of total deposits to total liabilities (Deposits/Liabilities). To the extent that a higher Deposits/Liabilities ratio implies that the bank has access to low cost, subsidized funding (deposits generally being an inexpensive source of funding and deposits generally enjoying government subsidized insurance), then a higher Deposits/Liabilities ratio might signal higher valuations. ${ }^{18}$ Third, we control for the book value capitalization of the bank (Equity/Assets). A well-capitalized bank may have fewer incentives to engage in excessive risktaking. If this were the case, we would expect a positive correlation between the ratio of book value of equity to total assets (Equity/Assets) and our excess valuation measure. We do not find that Equity/Assets enters with a statistically significant coefficient. ${ }^{19}$ Fourth, we control for past performance by including the growth rate in total assets over the last three years and or the growth

\footnotetext{
${ }^{18}$ We extended these analyses by multiplying each bank's Deposit/Liabilities ratio by the generosity of the deposit insurance regime of the bank's home country in order to provide a more precise estimate of the degree of government subsidization of each bank's liabilities. We obtain information on the generosity of the deposit insurance regime from Demirguc-Kunt and Detragiache (2002). Controlling for each bank's liability structure in this way does not affect the findings. We continue to find a diversification discount in financial conglomerates.

${ }^{19}$ The results are robust to controlling for the ownership structure of the bank. In particular, we control for the direct and indirect cash-flow rights of the controlling shareholder (CF). Caprio, Laeven, and Levine (2004) show that CF positively influences bank valuations. The reason is that controlling shareholders are less likely to expropriate bank resources when they have a larger stake in the future dividend streams of the bank. A controlling shareholder with substantial cash-flow rights also has greater incentives to monitor management in an effort to prevent empire building that satisfies managerial preferences for controlling a diverse financial conglomerate through value-destroying acquisitions and expansions. Including CF does not affect the finding of a diversification discount. We do not include these results in the table because including CF cuts the sample to less than 600 observations.
} 
rate in operating income over the last three years (Growth in assets and Growth in income respectively). ${ }^{20}$ Past performance is commonly used as a proxy for growth opportunities. When including these variables, however, income and asset diversity still enter negatively and significantly. Fifth, competition in the product market may influence the governance of banks, so that omitting information on the structure of the banking industry may lead to inappropriate inferences regarding the relationship between valuation and diversity. Toward this end, we include each bank’s market share of deposits as an indicator of the degree of competition facing the bank. ${ }^{21}$ Banks with a large market share may exert market power and enjoy correspondingly higher values. We find no evidence of this. More importantly for this paper's purposes, controlling for these banklevel variables does not affect the findings on income and asset diversity: There is still a significant diversification discount.

We also include country-level controls that vary over time (regressions 3, 4, 7, and 8 in Table 4), but this does not affect our findings. Specifically, we control for the current annual growth rate in the real Gross Domestic Product (GDP) per person to control for business cycle fluctuations and overall economic conditions. We also control for the current annual inflation rate since inflation can affect bank performance and may influence bank decisions to diversify into nonlending financial services (Boyd, Levine, and Smith, 2001).

Overall, we find that controlling for country traits and bank characteristics does not affect the negative relationship between diversity and excess valuation. Asset diversity enters all of the regressions in Table 4, Panel B negatively and significantly at the five percent level. The income diversity measure, which has the greater measurement error problems noted above, enters all of the

\footnotetext{
${ }^{20}$ Due to missing data on past growth rates in assets and income, the sample size in Table 4 is reduced by 642 bank-year observations. We obtain the same conclusions when we exclude these two growth rate variables.

${ }^{21}$ Using share of total assets instead of share of deposits does not change the conclusions.
} 
excess value regressions significantly at the five percent level and all of the Tobin’s q regression negatively and significantly at either the five or ten percent level.

In further robustness tests, we also controlled for an array of country traits that on a priori grounds may influence corporate governance and hence the linkages between excess value and the diversity of bank activities. Time-varying data do not exist on these variables, so the country fixed effects are dropped in these regressions. We do not create a separate table for these results and simply describe the findings. First, we controlled for cross-country differences in shareholder rights, as measured by La Porta et al (1998), since strong shareholder protection laws may mitigate agency problems between corporate insiders (managers and large shareholders) and small shareholders. Second, we controlled for the competitiveness of the banking industry, as measured by each country's level of banking sector concentration, since the degree of competitiveness in product markets may influence corporate governance. ${ }^{22}$ Third, we controlled for the generosity of the deposit insurance regime, as measured by Demirgüç-Kunt and Detragiache (2002), since generous deposit insurance may reduce the corporate governance role of depositors and hence influence the diversification discount. Fourth, we controlled for the degree of government ownership of banks, since government owned banks may inefficiently diversify into a range of activities. Thus, government intervention in banking could be the source of the diversification discount, not diversity per se. Finally, we controlled for cross-country differences in bank supervision and regulation, by using data from Barth et al (2001), since Barth et al (2004) and Demirguc-Kunt, Laeven, and Levine (2004) show that banking sector policies influence bank performance. Specifically, we controlled for reserve requirements, the ability of supervisory agencies to oversee and discipline banks, and the degree to which supervisors force accurate, timely information disclosure to the public. While some

\footnotetext{
${ }^{22}$ More specifically, we measure concentration as the percentage of total banking system assets held by the three largest banks. We compute this from the Bankscope database.
} 
of these country characteristics enter the regressions significantly, they do not change the finding of a negative relationship between diversity and valuation.

\section{Endogeneity, Extensions, and Additional Robustness Tests}

\section{A. Endogeneity}

Since financial institutions choose to diversify or not to diversify, the same bank-level characteristics that guide this decision may also affect the market's valuation of the bank. Thus, as argued by Campa and Kedia (2002), Chevalier (2000), Graham, Lemmon, and Wolf (2002), Lamont and Polk (2001), Maksimovic and Phillips (2002), Villalonga (2004a, b), Whited (2001), and others, failure to control for firm traits that drive the diversification decision may produce misleading econometric results that inappropriately attribute the diversification discount to diversification per se rather than to the underlying traits that induce firms to diversify. "A proper evaluation of the effect of diversification on firm value should take into account the firm-specific characteristics that bear both on firm value and on the decision to diversify." (Campa and Kedia, 2002, p. 1731)

To control for bank-specific traits and endogeneity concerns, we undertake four steps. First, we test whether bank-specific traits besides diversity drive the results. In addition to controlling for the wide range of bank-specific characteristics described above, regression (1) in Panels A and B of Table 5 includes fixed effects for each bank (and each year). The bank fixed effect regressions confirm the results. Furthermore, these results hold when we also include the time-varying bankspecific variables from Table 4 in these regressions.

Second, we use four instrumental variable (IV) specifications. Country factors may induce both diversification and the conglomerate discount. If diversity varies systematically across 
countries and if including country-fixed effects does not fully capture this effect, then the diversification discount may reflect cross-country rather than cross-bank variation. Thus, simultaneity bias may invalidate the interpretation of the coefficient on diversity. We address this potential bias by using an index of regulatory restrictions on bank activities as an instrument for the diversity variable. The index of regulatory restrictions is from Barth, Caprio, and Levine (2004) and is increasing in regulatory restrictions on the degree to which banks can engage in underwriting, brokering and dealing in securities. ${ }^{23}$ Thus, we relate banks' market valuations to the exogenous variation in the structure of financial institutions. ${ }^{24}$

The second IV specification uses a measure of regulatory restrictions on bank entry as an instrumental variable for diversity. From Barth, Caprio, and Levine (2004), we use the fraction of banking license applications denied by the regulatory authority as a proxy for restrictions on the entry of new banks. ${ }^{25}$ A higher score indicates greater restrictions on entry. For our sample, the entry variable ranges from 0 to 1 , with a mean of 0.28 . In more protected banking environments, bankers may have greater latitude to engage in activities that extract private benefits from the bank, including diversifying into other financial activities.

\footnotetext{
${ }^{23}$ The index of regulatory restrictions equals one if the full range of activities can be conducted directly in the bank. It equals two if the full range of activities can be conducted, but some or all must be conducted in subsidiaries. The index equals three if less than full range of securities market activities can be conducted in the bank or subsidiaries. The index equals four if securities activities are prohibited, i.e., they cannot be conducted in either the bank or subsidiaries. No country in our sample has a value of four. The mean for our sample is 1.6.

${ }^{24}$ We do not include the bank-specific control variables used in Table 4 in the IV regressions because they are potentially endogenous and we do not have valid instruments for these variables. Including these endogenous variables could bias the IV results. Concerns about biasing the coefficient estimates by including endogenous bank-specific regressors do not hold for the bank fixed effect regression or the Heckman self-selection estimation in Table 5. For these regressions, including the bank-specific control variables from Table 4 does not alter the results.

${ }^{25}$ One potential shortcoming with this measure of regulatory restrictions on the entry of new banks is that if there are zero applications - which may indicate the presence of insurmountable entry barriers that discourage potential banks from completing an application - this variable is not defined. However, when we replace the missing values with ones in those countries that received zero entry application, the results hold.
} 
The third IV specification uses the average income (asset) diversity of other financial institutions in the economy as an instrumental variable for each bank's degree of income (asset) diversity. This is an alternative way of abstracting from country factors that induce diversification.

The fourth IV specification is motivated by the instruments employed by Campa and Kedia's (2002) examination of industrial conglomerates. Following their work, we include as instruments the logarithm of total assets and the return on assets to control for the size and performance of financial institutions since these characteristics may influence diversification decisions. We also include the share of diversified banks in the country as an instrument, since, as discussed above, there may be country-specific factors that influence the attractiveness of diversification. The instrument set also contains a dummy variable for whether the financial institution is listed on the New York Stock Exchange (NYSE), since listing on a major exchange may give the financial institution greater visibility, reduce information costs, and lower the cost of capital and thereby make it easier to diversify. Similarly, since banks with more liquid equities might enjoy higher relative valuations, we use a dummy variable for whether the bank belongs to the S\&P financial index as an instrument for diversity. Besides using instrumental variables to extract the exogenous component of diversity, the analyses include year dummy variables and adjust the standard errors for clustering at the bank-level. The fourth IV specification also includes country dummy variables.

Using any of the four sets of instrumental variables, the regression results continue to indicate a diversification discount in financial conglomerates. The first set of IV results that use the index of regulatory restrictions on commercial bank activities as an instrument are presented in column (2) of Table 5 (both Panels A and B on income and asset diversity respectively). As shown, income diversity and asset diversity remain negatively and significantly associated with excess 
value. As expected, the first stage regression results show that banks are more diversified in countries that place fewer restrictions on banking activities. The second set of IV results uses the fraction of entry applications denied as an instrument for diversity (column 3). These IV results also confirm the finding of a diversification discount in financial conglomerates. Also, the first stage regression indicates that the degree of regulatory restrictions on the entry of new banks is positively related to diversity. These results are consistent with the agency story in Fama and Jensen (1983) and Jensen (1986) who argue that bank managers are better able to consume private benefits (arising from diversification) when product-market competition is less vigorous. The third set of IV results use the average diversity of other banks in the country as an instrument, and are presented in Table 5's column (4) for both income diversity (Panel A) and asset diversity (Panel B). Income diversity enters negatively and significantly at the ten percent level (Panel A), while asset diversity enters negatively and significantly at the five percent level. The fourth set of IV results, which are based on a more comprehensive set of instruments and with correspondingly higher first-stage Rsquares, produce even stronger results. As shown in column (5) of Table 5, both income diversity and asset diversity enter the excess value equation negatively and significantly at the five percent level. The instrumental variable regressions are consistent with the view that diversity in financial conglomerates destroys value.

Third, we use Heckman's (1979) two-step procedure to control for endogeneity. The goal is to control for the self-selection bias created by banks' choosing to diversify by incorporating the diversification decision formally into the econometric estimation. In the first-step, we estimate whether the bank is diversified. Thus, depending on whether we are examining income or asset diversity, the dependent variable in the first-step is either (a) a dummy variable that equals one if the net interest income is between 10 and 90 percent of total income, or (b) a dummy variable that 
equals one if loans account for between 10 and 90 percent of total earning assets. Thus, the first-step involves a probit estimation where the explanatory variables are the instrumental variables used in regressions 5 of Table 5: the logarithm of total assets, return on assets, share of diversified banks in the economy, a dummy variable for whether the bank is included in the S\&P financial index, and a dummy variable for whether the bank is listed on the NYSE. In the second stage, excess value is the dependent variable. While controlling for self-selection bias, the second stage yields estimates of (1) the relationship between diversity and excess value and (2) the self-selection parameter (Lambda).

The results of the two-step estimation of the endogenous self-selection model confirm the existence of a diversification discount in financial conglomerates. The results on income diversity are reported in column (6) of Panel A in Table 5, while the asset diversity results are given in Panel B. In the excess value equation, both income diversity and asset diversity enter negatively and significantly. The selection parameter, Lambda, is negative but insignificant for the income diversity regression (Panel A). The negative coefficient on Lambda suggests that bank characteristics that are associated with banks diversifying are negatively correlated with excess value. But, Lambda is insignificant, suggesting that self-selection is not driving the results. Moreover, Lambda is positive, but again insignificant, in the asset diversity regression (Panel B). Thus, the self-selection model confirms the results. These results are robust to including the bankspecific variables from Table 4 .

In sum, unlike the findings in industrial conglomerates (e.g., Campa and Kedia, 2002; Maksimovic and Phillips, 2002), we do not find that simultaneity bias produces the diversification discount in financial conglomerates. When using bank fixed effects, employing instrumental variables, or estimating a self-selection model, we continue to find that diversity per se lowers market valuations. 


\section{B. Scale and Scope of Specialized and Diversified Banks}

Maksimovic and Phillips (2002) develop a model that clarifies some conditions under which conglomerate firms are less productive than specialized firms, but the resultant diversification discount has nothing to do with diversification destroying value. They note that firms may differ in terms of expansion opportunities/capabilities. They assume that there are diminishing returns within each activity. Thus, a firm that is highly productive in activity A faces higher opportunity costs associated with diversifying into activity B than a firm that is less productive in activity A. This yields the prediction that those firms that are most productive will be less likely to expand into new activities and instead expand within their own specialized area, which implies that a specialized firm in activity A will tend to be larger than a conglomerate firm's operations in activity A.

Although our paper is different in that we examine diversification within the financial services industry, we are still concerned that bank specific differences may drive the results. Besides the assortment of econometric procedures that we use to control for endogeneity in Table 5, Table 6 provides further information. Table 6 summarizes differences between diversified and specialized financial intermediaries by presenting regressions of bank characteristics on dummy variables that indicate whether the bank is a specialized commercial bank or a specialized investment bank. The default category is a diversified bank.

The Table 6 results do not support the view that banks that lack expansion opportunities in one activity diversify into other activities. Diversified banks do not have smaller loan portfolios than specialized commercial banks, nor do diversified banks have smaller fee/transaction based activities than specialized investment banks. Thus, the data are inconsistent with the view that, for example, a productive lending bank keeps expanding its lending operations, while a less productive 
lending bank expands into investment banking. Rather, financial conglomerates tend to be larger than specialized commercial banks even within the specialized activity of lending.

\section{Controlling for Mergers}

Furthermore, mergers can bias the diversification results. ${ }^{26}$ In particular, Graham, Lemmon, and Wolf (2002) use data from Compustat and information on mergers to assess whether the diversification discount provides misleading inferences because there are systematic differences between the divisions of conglomerates and the specialized firms against which they are benchmarked in the "chop-shop" approach. They find that target firms are already discounted. Thus, they argue that the diversification discount does not arise because diversification destroys value. Rather, they argue that conglomerates purchase discounted target firms, so that the chop-shop approach yields a discount.

Although we do not have sufficiently detailed information on all mergers to replicate the Graham, Lemmon, and Wolf (2002) analysis for the case of banks, we control for the possible impact of mergers in two ways. First, we trace the history of every bank in our sample to examine whether they had recently undergone an important merger or acquisition. Specifically, for every bank and every year, we determine whether the bank merged with or acquired at least one other financial institution such that there was a change in the name of the financial institution. Then, we create a dummy for each bank that equals one in the year of the merger or acquisition. To assess whether mergers affect excess value with a lag, we also include lagged values of this merger/acquisition dummy variable. Second, we identify all financial intermediaries that experienced a change in assets of more than $50 \%$ from year $t-1$ to year $t$, which may reflect a large

\footnotetext{
${ }^{26}$ There exists a large literature on the net gains to shareholders of bank mergers. Houston et al (2001) find for the period 1985 to 1996 that bank mergers in the United States have been value enhancing, largely because they generated cost savings.
} 
acquisition. We then exclude observations on that intermediary for year $t$ and all later years. While large changes in assets may reflect other phenomenon, this represents an additional way of accounting for the possible impact of mergers and acquisitions on the results.

As shown in Table 7, controlling for major mergers and acquisition in these ways does not affect the results on the diversification discount. Income diversity and asset diversity continue to enter negative and significantly. The merger/acquisition dummy variables do not affect the findings on diversity and the dummy variables do not enter significantly. Similarly, excluding financial institutions that experienced a large change in assets does not affect the results. By controlling for mergers and acquisitions that are likely to affect valuations substantially and by controlling for endogeneity, this allays concerns that we are misinterpreting the diversification discount.

\section{Controlling for Insurance Activities}

As an extension, we also include insurance activities in the analysis. From Bankscope, we have information on banks and investment banks as discussed above. We also have information on four bancassurance companies, which are in Bankscope but also included in Worldscope as insurance companies. These four companies are Fortis, Sampo, Irish Life \& Permanent, and ING Groep.

Table 8 indicates that controlling for insurance activities in our analyses does not affect the results. In columns (1) and (3), we simply eliminate the four bancassurance companies (17 conglomerate-year observations) from our standard analyses. Thus, the dependent variable is excess value and we control for income and asset diversity respectively. Excluding these financial firms does not change the results. In columns (2) and (4), we use dummy variables for these four financial firms. Again, this does not change the results. 
Next, we confirm the existence of a diversification discount in financial conglomerates when extending the chop-shop approach to also include insurance activities (besides commercial banking and investment banking). We obtain information on insurance companies from Worldscope (1428 firm-year observations over the period 1998-2002). We only include insurance companies because Bankscope does not have insurance information on banks. In this robustness test, we compute excess values using a three-dimensional chop-shop approach rather than the two dimensional approach based on commercial and investment banking activities described above. Specifically, the dependent variable in column (5) is the difference between actual $q$ and activity-adjusted $q$ (excess value) based on income diversity, where we consider three sources of operating income: interest income, premium income, and other income (including income from fees and commissions). We use the global sample of insurance companies in Worldscope that are not included as banks in Bankscope to calculate the average $q$ of stand-alone insurance companies. Activity-adjusted $q$ is therefore calculated as follows: (Net Interest income/Total operating income)*Average $q$ of pure commercial banks + (Net premium income /Total operating income) *Average $q$ of pure insurance companies $+($ Other income/Total operating income $) *$ Average $q$ of pure investment banks. Similarly, the income diversity with insurance variable considers three rather than two sources of income: interest income, premium income and other income. To calculate net premium income, we subtract net claims arising from insurance activities from premium income. The variable is constructed such that 0 denotes no diversity (one source of income) and 1 denotes high diversity (all three sources have equal share in total income). ${ }^{27}$ As shown in column five, diversity is negatively associated with excess value when extending the analyses to include insurance activities.

\footnotetext{
${ }^{27}$ The variable is calculated as follows: For banks without insurance activities: 1-|(Net interest income-Other income)/Total operating income|. For banks with insurance activities: 1 - |Net interest income/Total operating income $(1 / 3) \mid$ - |Net premium income/Total operating income - (1/3)| - |Other income/Total operating income - (1/3)|, where |.| denotes the absolute value indicator.
} 


\section{$\underline{\text { E. Sub-Samples }}$}

Next, we investigate whether the results are sensitive to examining sub-samples of banks, excluding U.S. banks, only examining U.S. banks, or weighting observations differently.

First, we restrict the sample to diversified banks, i.e., firms for which the Diversity dummy variables used in the previous section take a value of one (column (1) in Table 9). The results are not affected.

Second, we restrict the sample to commercial banks only, as defined by the Bankscope database, thereby excluding investment banks but also savings banks, cooperative banks, and bank holding companies (column (2) in Table 9). The advantage of focusing on commercial banks is that the group of firms is more comparable and less diverse. Again, the results are very similar.

Third, we exclude U.S. banks from the sample. We want to make sure that the results are not driven by the U.S. banking system, which is quite special in the senses that it (i) has many small banks and (ii) has only recently allowed commercial banks to engage in investment banking activities. The results are presented in column (3) of Table 9. The findings are very similar.

Fourth, we examine only U.S. banks. In doing this, we first present the results when continuing to use the global sample of banks to compute the valuation of pure activity banks (column 4) and then we present the results when using only U.S. banks to compute pure activity q's (column 5). Looking at only U.S. banks is less informative than examining the full sample in the sense that the Gramm-Leach-Bliley Act only recently (formally) expanded the range of permitted bank activities. Indeed, looking at banks outside of the United States that have historically had fewer regulatory impediments to diversifying activities may provide information regarding future developments within the U.S. financial services industry. Nevertheless, we provide the U.S. only 
results for completeness. As shown, while the results are not statistically significant for the Income diversity measure when focusing on U.S. banks (columns (4) and (5) of Panel A), the results do hold when using the Asset Diversity measure (columns (4) and (5) of Panel B). As noted, we believe the Asset diversity measure is a more accurate measure of diversity because loan-making banks may charge fees to generate income, which would distort the income measure. The use of fees in loan-making may be more pronounced in U.S. banks. This distortion of diversity is less likely for the asset based measure. Thus, we place more weight on the Asset diversity results.

Finally, we use weighted least squares, with the inverse of the number of country observations (sampled banks) as weights, to verify that our results are not driven by differences in the number of (sampled) banks across countries. The results still indicate a diversification discount in financial conglomerates (column (6) of Table 9).

\section{$\underline{\text { F. Alternative Valuation and Performance Measures }}$}

We consider alternative measures of firm valuation and performance. ${ }^{28}$ Thus far, we have used the average $q$ of single-activity banks to construct activity-adjusted q's. Due to the sampling variation in $q$ for single activity banks, we test whether the results are robust to using the median value of $q$ of single-activity banks instead. The results hold (columns (1) and (4) of Table 10).

\footnotetext{
${ }^{28}$ We have also checked the robustness of our results to the use of alternative diversity measures and possible nonlinearities in the relationship between diversity and valuations. First, we use dummy variable to assess whether the relationship between diversification and valuation is more pronounced at high levels of diversity. We construct a dummy variable that equals one if Income (Asset) Diversity is between 2/3 and 1, and zero otherwise. Indeed, we find a statistically significant and negative effect on excess valuation at higher levels of income or asset diversity. Second, rather than using fixed and equidistant cutoffs (such as 0.1 and 0.9 ) to calculate the diversity measures, we test whether the results are sensitive to using cutoffs that are based on the sample characteristics. In particular, we use the 10th and 90th percentiles as cutoff of the diversity variables to construct the two diversity and excess value measures. While the percentiles imply rather different cutoff levels for the diversity variables, the results are similar. We also obtain similar results when we use the 3-year average of income diversity instead of the current value. Third, we combine data on both income and asset diversity to produce two conglomerate indexes of diversity: the average of the income diversity and asset diversity variables, and a dummy variable that takes value of one if the realizations of both income and asset diversity are between 0.1 and 0.9 . The results continue to indicate a diversification discount (not shown).
} 
Next, we use the sample of U.S. banks only rather than the global sample of banks to calculate the average $q$ of single-activity banks and our excess value measures. Using data on $q$ from one country has the advantage that we can focus on within-country variation in $q$. Crosscountry variation in $q$ can be subsumed in country fixed effects. Ideally, we would want to calculate activity-adjusted $q$ 's for each country using banks in that country only. Unfortunately, most countries do not have enough banks to implement this in practice. The results when using excess values constructed using a sample of single activity banks from the U.S. are reported in columns (2) and (5) of Table 10. The results do not change when using the U.S.-based measure of excess value. In columns (3) and (6) of Table 10, we use a measure of excess performance based on the firm's operating income rather than Tobin's $q$. The measure is constructed in a similar fashion as the excess value measure described earlier, but uses data on operating income rather than Tobin's $q$. The results are qualitatively similar when using this alternative measure of firm performance. Banks that diversify into multiple activities are not only valued less by the market but also show worse performance on average as measured by total operating income. 


\section{Concluding Remarks}

This paper finds that markets value financial conglomerates that engage in multiple activities lower than if those financial conglomerates were broken into financial intermediaries that specialize in the individual activities. To identify the independent impact of diversity on valuation, we employ a number of econometric procedures that control for the possibility that the same characteristics that induce financial institutions to diversify also lower market valuations. Across an array of sensitivity checks, the data suggest that diversity reduces the value of financial conglomerates. One explanation of these results is that financial conglomerates that engage in multiple activities intensify agency problems and destroy value. Although we attempt to control for alternative explanations, we do not directly measure agency problems and therefore we cannot directly link the results to a single causal factor. The results, however, do show that economies of scope in financial intermediation are not sufficiently large to compensate for countervailing forces associated with diversification since we consistently find a diversification discount, never a diversification premium.

The paper contributes to two interrelated strands of research. First, while some policymakers, practitioners, and researchers trumpet economies of scope from one-stop shopping for financial services, others stress intensified agency problems associated with monitoring complex financial conglomerates. We find that markets attach a discount to financial institutions that engage in diverse activities. Second, this paper contributes to the broader literature on corporate diversification by examining diversification within one industry, rather than examining diversification across very different activities. After controlling for endogeneity and other possible explanations, we find a diversification discount even within an industry likely to enjoy economies of scope. 


\section{References}

Adams, R., Mehran, H., 2003. Is corporate governance different for bank holding companies? Economic Policy Review 9, 123-142.

Allen, L., Rai, A., 1996. Operational efficiency in banking: An international comparison. Journal of Banking and Finance 18, 655-672.

Amihud, Y., Lev, B., 1981. Risk reduction and managerial motive for conglomerate mergers. Bell Journal of Economics 12, 605-617.

Aron, D., 1988. Ability, moral hazard, firm size, and diversification. The Rand Journal of Economics 19, 72-87.

Barth, J., Caprio, G., Levine, R., 2001. The regulation and supervision of banks around the world: A new database. In: Brooking-Wharton Papers on Financial Services, Eds: Litan, R. and R. Herring, Washington, DC, Brookings Institution, 183-250.

Barth, J., Caprio, G., Levine, R., 2004. Bank supervision and regulation: What works best? Journal of Financial Intermediation 13, 205-248.

Benston, G., 1994. Universal banking. Journal of Economic Perspectives 8, 121-143.

Benzoni, L., Schenone, C., 2005. Conflict of interest or certification? Evidence from IPOs underwritten by the firm's relationship bank. Working paper, University of Minnesota.

Ber, H., Yafeh, Y., Yosha, O., 2001. Conflict of interest in universal banking: Bank lending, stock underwriting, and fund management. Journal of Monetary Economics 47, 189-218.

Berger, A., Demsetz, R., Strahan, P., 1999. The consolidation of the financial services industry: Causes, consequences, and implications for the future. Journal of Banking and Finance 23, 135-194.

Berger, A., Hanweck, G., Humphrey, D., 1987. Competitive viability in banking: Scale, scope, and product mix economies. Journal of Monetary Economics 20, 501-520.

Berger, A., Humphrey, D., 1991. The dominance of inefficiencies over scale and product mix economies in banking. Journal of Monetary Economics 28, 117-148.

Berger, P., Ofek, E., 1995. Diversification's effect on firm value. Journal of Financial Economics 37, 39-65.

Boyd, J., Chang, C., Smith, B., 1998. Moral hazard under commercial and universal banking. Journal of Money, Credit, and Banking 30, 426-468. 
Boyd, J., Levine, R., Smith, B., 2001. The impact of inflation on financial sector performance. Journal of Monetary Economics 47, 221-48.

Brook, Y., Hendershott, R., Lee, D., 1998. The gains from takeover deregulation: Evidence from the end of interstate banking restrictions. Journal of Finance 53, 2185-2204.

Campa, J., Kedia, S., 2002. Explaining the diversification discount. Journal of Finance 57, 17311762.

Caprio, G., Laeven, L., Levine, R., 2004. Governance and bank valuation. NBER Working Paper No. 10158.

Chandler, A., 1977. The Visible Hand. Cambridge, MA: Belknap Press.

Chevalier, J., 2000. Why do firms undertake diversifying mergers? An analysis of the investment policies of merging firms. Working paper, University of Chicago.

Coase, R., 1937. The nature of the firm. Economica 4, 386-405.

Comment, R., Jarrell, G., 1995. Corporate focus and stock returns. Journal of Financial Economics 37, 67-87.

DeLong, G., 2001. Stockholder gains from focusing versus diversifying bank mergers. Journal of Financial Economics 59, 221-252.

Demirgüç-Kunt, A., Detragiache, E., 2002. Does deposit insurance increase banking system stability? An empirical investigation. Journal of Monetary Economics 49, 1373-1406.

Demirgüç-Kunt, A., Laeven, L., Levine, R., 2004. Regulations, market structure, institutions, and the cost of financial intermediation. Journal of Money, Credit, and Banking 36, 593-622.

Demsetz, H., Lehn, K., 1985. The structure of corporate ownership: Causes and consequences. Journal of Political Economy 93, 1155-1177.

Denis, D., Denis, D., Sarin, A., 1997. Agency problems, equity ownership, and corporate diversification, Journal of Finance 52. 135-160.

Diamond, D., 1984. Financial intermediation and delegated monitoring, Review of Economic Studies 51, 393-414.

Diamond, D., 1991. Monitoring and reputation: The choice between bank loans and directly placed debt. Journal of Political Economy 99, 689-721.

Drucker, S., Puri, M., 2005. On the benefits of concurrent lending and underwriting. Journal of Finance forthcoming. 
Fama, E., Jensen, M., 1983. Separation of ownership and control. Journal of Law and Economics 26, 301-325.

Ferrier, G., Grosskopf, S., Hayes, K., Yaisawarng, S., 1993. Economies of diversification in the banking industry: A frontier approach. Journal of Monetary Economics 31, 229-49.

Flannery, M., Kwan, S., Nimalendran, M., 2002. Market evidence on the opaqueness of banking. Mimeo, University of Florida.

Fluck, Z., Lynch, A., 1999. Why do firm merge and then divest? A theory of financial synergies. Journal of Business 72, 319-346.

Gande, A., Puri, M., Saunders, A., Walter, I., 1997. Bank underwriting of debt securities: Modern evidence. Review of Financial Studies 10, 1175-1202.

Gande, A., Puri, M., Saunders, A., 1999. Bank entry, competition, and the market for corporate securities underwriting. Journal of Financial Economics 54, 165-195.

Gertner, R., Scharfstein, D., Stein, J., 1994. Internal vs. external capital markets. Quarterly Journal of Economics 109, 1211-1230.

Graham, J., Lemmon, M., Wolf, J., 2002. Does corporate diversification destroy value? Journal of Finance 57, 695-720.

Haubrich, J., Santos, J., 2004. Banking and commerce: A liquidity approach. Journal of Banking and Finance, forthcoming.

Heckman, J., 1979. Sample selection bias as a specification error. Econometrica 47, 153-161.

Houston, J., James, C., Marcus, D., 1997. Capital market frictions and the role of internal capital markets in banking. Journal of Financial Economics 46, 135-164.

Houston, J., James, C., Ryngaert, M., 2001. Where do merger gains come from? Bank mergers from the perspective of insiders and outsiders. Journal of Financial Economics 60, 285-331.

Jensen, M., 1986. Agency costs of free cash flow, corporate finance, and takeovers. American Economic Review 76, 323-329.

Jensen, M., Meckling, W., 1976. Theory of the firm: Managerial behavior, agency costs, and ownership structure. Journal of Financial Economics 3, 305-360.

John, K., Ofek, E., 1995. Asset sales and increase in focus. Journal of Financial Economics 37, 105-126.

Kroszner, R., Rajan, R., 1994. Is the Glass-Steagall Act justified? A study of the U.S. experience with universal banking before 1933. American Economic Review 84, 810-832. 
Lamont, O., Polk, C., 2001. The diversification discount: Cash flows versus returns. Journal of Finance 56, 1693-1721.

La Porta, R., Lopez-de-Silanes, F., Shleifer, A., Vishny, R., 1998. Law and finance. Journal of Political Economy 106, 1113-1155.

Lang, L., Stulz, R., 1994. Tobin’s Q, corporate diversification, and firm performance. Journal of Political Economy 102, 1248-1280.

LeBaron, D., Speidell, L., 1987. Why are the parts worth more than the sum? 'Chop shop,' a corporate valuation model. In: L. Browne and E. Rosengren, The Merger Boom, Conference Series no. 31. Boston: Federal Reserve Bank.

Lins, K., Servaes, H., 1999. International evidence on the value of corporate diversification. Journal of Finance 54, 2215-1139.

Maksimovic, V., Phillips, G., 2002. Do conglomerate firms allocate resources inefficiently across industries? Theory and evidence. Journal of Finance 57, 721-767.

Michaely, R., Womack, K., 1999. Conflict of interest and the credibility of underwriter analyst recommendations. Review of Financial Studies 12, 653-686.

Morck, R., Shleifer, A., Vishny, R., 1990. Do managerial objectives drive bad acquisition? Journal of Finance 45, 31-48.

Morgan, D., 2002. Rating banks: Risk and uncertainty in an opaque industry. American Economic Review 92, 874-88.

Penas, M., Unal, H., 2005. Gains in bank mergers: Evidence from the bond markets. Journal of Financial Economics, forthcoming.

Petersen, M., Rajan, R., 1994. The benefits of lending relationships: Evidence from small business data. Journal of Finance 49, 3-37.

Pulley, L., Humphrey, D., 1993. The role of fixed costs and cost complementarities in determining scope economies and the costs of narrow banking proposals. Journal of Business 66, 437462.

Puri, M., 1996. Commercial banks in investment banking: conflicts of interest or certification role. Journal of Financial Economics 40, 373-401.

Rajan, R., 1992. Insiders and outsiders: The choice between informed and arm's-length debt. Journal of Finance 47, 1367-1400. 
Rajan, R., Servaes, H., Zingales, L., 2000. The cost of diversity: The diversification discount and inefficient investment. Journal of Finance 55, 35-80.

Rotemberg, J., Saloner, G., 1994. Benefits of narrow business strategies. American Economic Review 84, 1330-1349.

Saunders, A., Walter, I., 1994. Universal Banking in the United States: What Could We Gain? What Could We Lose? Oxford University Press.

Schenone, C., 2004. The effect of banking relationships on the firm's IPO underpricing. Journal of Finance 59, 2903-2958.

Schoar, A., 2002. Effects of corporate diversification on productivity. Journal of Finance 57, 23792403.

Servaes, H., 1996. The value of diversification during the conglomerate merger wave. Journal of Finance 51, 1201-1225.

Stein, J., 2002. Information production and capital allocation: Decentralized versus hierarchical firms. Journal of Finance 57, 1891-1921.

Stulz, R., 1990. Managerial discretion and optimal financial policies. Journal of Financial Economics 26, 3-27.

Sufi, A., 2004. Does joint production of lending and underwriting help or hurt firms? A fixed effects approach. MIT (Department of Economics), mimeo.

Vander Vennet, R., 2002. Cost and profit efficiency of financial conglomerates and universal banks in Europe. Journal of Money, Credit and Banking 34, 254-282.

Villalonga, B., 2004a. Diversification discount or premium? New evidence from the business information tracking series. Journal of Finance 59, 479-506.

Villalonga, B., 2004b. Does diversification cause the 'diversification discount'? Financial Management 33, 5-27.

Williamson, O., 1970. Corporate Control and Business Behavior: An Inquiry into the Effects of Organizational Form on Enterprise Behavior. Englewood Cliffs, NJ: Prentice-Hall. 
Tobin's q is calculated as the ratio of (the market value of common equity plus the book value of preferred shares plus the book value of total debt) to (the book value of total assets). Net interest income is interest income minus interest expense. Other operating income includes net fee income, net commission income, and net trading income. Income diversity is a measure of diversification across different sources of income and is calculated as 1-|(Net interest income-Other operating income)/Total operating income|. Income diversity takes values between 0 and 1 and is increasing in the degree of diversification. Asset diversity is a measure of diversification across different types of assets and is calculated as 1-|(Net loans-Other earning assets)/Total earning assets|. Other earning assets include securities and investments. Asset diversity takes values between 0 and 1 and is increasing in the degree of diversification. We include all listed banks from Bankscope (except banks classified by Bankscope as non-banking credit institutions, Islamic banks, real estate banks, or specialized governmental credit institutions). We exclude banks with less than US\$ 100 million in total assets. We exclude observations without basic accounting information (i.e., missing values for total assets, earning assets, operating income, equity, and market value). We also exclude extreme outliers in the main variables (i.e., more than 4 standard deviations from the mean). Data are for the years 1998-2002.

\begin{tabular}{|c|c|c|c|c|c|c|c|c|}
\hline \multirow[b]{2}{*}{ Variable } & \multirow[b]{2}{*}{ Sample size } & \multirow[b]{2}{*}{ Mean } & \multirow[b]{2}{*}{ Median } & \multirow[b]{2}{*}{$\begin{array}{l}\text { Standard } \\
\text { deviation }\end{array}$} & \multicolumn{4}{|c|}{ Correlation (p-value) } \\
\hline & & & & & $\begin{array}{c}\text { Interest income } \\
\text { to total } \\
\text { operating } \\
\text { income }\end{array}$ & $\begin{array}{l}\text { Loans to total } \\
\text { earning assets }\end{array}$ & $\begin{array}{l}\text { Income } \\
\text { diversity }\end{array}$ & Asset diversity \\
\hline Tobin’s q & 3415 & 1.06 & 1.02 & 0.16 & $\begin{array}{c}-0.35 \\
(0.00)\end{array}$ & $\begin{array}{l}-0.15 \\
(0.00)\end{array}$ & $\begin{array}{l}-0.08 \\
(0.00)\end{array}$ & $\begin{array}{l}-0.06 \\
(0.00)\end{array}$ \\
\hline Net interest income to total operating income & 3415 & 0.66 & 0.70 & 0.20 & 1.00 & $\begin{array}{c}0.52 \\
(0.00)\end{array}$ & $\begin{array}{l}-0.26 \\
(0.00)\end{array}$ & $\begin{array}{l}-0.00 \\
(0.89)\end{array}$ \\
\hline Loans to total earning assets & 3415 & 0.66 & 0.69 & 0.18 & & 1.00 & $\begin{array}{c}0.10 \\
(0.00)\end{array}$ & $\begin{array}{l}-0.39 \\
(0.00)\end{array}$ \\
\hline Income diversity & 3415 & 0.54 & 0.53 & 0.23 & & & 1.00 & $\begin{array}{c}0.15 \\
(0.00)\end{array}$ \\
\hline Asset diversity & 3415 & 0.58 & 0.57 & 0.23 & & & & 1.00 \\
\hline
\end{tabular}




\section{Table 2}

\section{Excess Value of Diversified Banks}

The excess value for a diversified bank is the difference between its actual q and its activity-adjusted q. The activity-adjusted q of a bank is the weighted average of pure commercial banking and pure investment banking q's. The weights are based on the relative importance of interest income to total operating income in the case of the income diversity measure and the relative importance of loans to total earning assets in the case of the asset diversity measure. In the case of the income diversity, the pure commercial banking $q$ is proxied by the average of the q's of banks with a ratio of interest income to total operating income of 0.9 or higher and the pure investment banking q is proxied by the average of the q's of banks with a ratio of interest income to total operating income of 0.1 or lower. In the case of the asset diversity, the pure commercial banking q is proxied by the average of the q's of banks with a ratio of loans to total earning assets of 0.9 or higher and the pure investment banking q is proxied by the average of the q's of banks with a ratio of loans to total earning assets of 0.1 or lower. The row labeled "unadjusted excess value" provides the regression coefficient and t-statistic on the diversification dummy variable (income diversity and asset diversity respectively) from a regression of q on a constant, country dummy variables, year dummy variables, and the corresponding diversification dummy variable. A banking firm is defined to be diversified if the ratio of interest income to total operating income is between 0.1 and 0.9 or if the ratio of loans to total earning assets is between 0.1 and 0.9. Data are for the years 1998-2002. * significant at 10\%; ** significant at 5\%; *** significant at $1 \%$.

\begin{tabular}{|c|c|c|}
\hline Variable & Income diversity & Asset diversity \\
\hline Mean excess value (t-statistic) & $\begin{array}{c}-0.055^{* * *} \\
(23.11)\end{array}$ & $\begin{array}{c}-0.065 * * * \\
(21.56)\end{array}$ \\
\hline Median excess value (p-value for non-parametric sign test) & $\begin{array}{c}-0.061 * * * \\
(0.000)\end{array}$ & $\begin{array}{c}-0.070 * * * \\
(0.000)\end{array}$ \\
\hline Unadjusted excess value (t-statistic) & $\begin{array}{c}-0.066 * * * \\
(3.01)\end{array}$ & $\begin{array}{c}-0.071^{* *} \\
(2.55)\end{array}$ \\
\hline
\end{tabular}


Table 3

Diversity, Excess Value, and Tobin’s q

The dependent variable in column (1) is the difference between actual q and activity-adjusted q (excess value) based on income diversity. The dependent variable in column (2) is the difference between actual q and activity-adjusted q (excess value) based on asset diversity. The dependent variable in columns (3) and (4) is Tobin's q. The regressions include country and year dummies (not reported). Standard errors are adjusted for clustering at the bank-level. The sample includes all firms, including those identified as pure-activity firms. Data are for the years 1998-2002. * significant at 10\%; ** significant at 5\%; *** significant at $1 \%$.

\begin{tabular}{|c|c|c|c|c|}
\hline & $(1)$ & $(2)$ & (3) & (4) \\
\hline & \multicolumn{2}{|c|}{ Excess value } & \multicolumn{2}{|c|}{ Tobin’s Q } \\
\hline & Income diversity & Asset diversity & Income diversity & Asset diversity \\
\hline Income diversity & $\begin{array}{c}-0.103^{* *} \\
(0.044)\end{array}$ & & $\begin{array}{c}-0.106 * * \\
(0.049)\end{array}$ & \\
\hline Net interest income to total operating income & & & $\begin{array}{c}-0.240 * * * \\
(0.059)\end{array}$ & \\
\hline Asset diversity & & $\begin{array}{c}-0.130 * * * \\
(0.035)\end{array}$ & & $\begin{array}{c}-0.099 * * \\
(0.046)\end{array}$ \\
\hline Loans to total earning assets & & & & $\begin{array}{c}-0.194 * * * \\
(0.065)\end{array}$ \\
\hline Observations & 3415 & 3415 & 3415 & 3415 \\
\hline Number of banks & 867 & 867 & 867 & 867 \\
\hline Number of countries & 43 & 43 & 43 & 43 \\
\hline R-squared & 0.15 & 0.21 & 0.19 & 0.15 \\
\hline
\end{tabular}


Table 4 Diversity and Excess Value: Controlling for Bank-Level and Country-Level Characteristics

The dependent variable in panel A, columns (1) to (4), is the difference between actual q and activity-adjusted q (excess value) based on income diversity. The dependent variable in panel B, columns (1) to (4), is the difference between actual q and activity-adjusted q (excess value) based on asset diversity. The

dependent variable in columns (5) to (8) is unadjusted q. Log(total assets) is the logarithm of the bank's total assets. Log(total operating income) is the logarithm of the bank's total operating income. Deposits/Liabilities is the ratio of total deposits to total liabilities. Equity/Assets is the ratio of book value of equity to total assets. Growth in assets is the 3-year growth rate in total assets. Growth in income is the 3-year growth rate in operating income. Market share of deposits is the bank's share in total bank deposits in the country. GDP per capita growth is the annual real growth in GDP per capita. Inflation is the annual change in the CPI index. We include country dummies and year dummies (not reported). Standard errors are adjusted for clustering at the bank-level. Data for the years 1998-2002.

* significant at $10 \%$; ** significant at $5 \%$; *** significant at $1 \%$.

Panel A: Income diversity

\begin{tabular}{|c|c|c|c|c|c|c|c|c|}
\hline & $(1)$ & $(2)$ & (3) & $(4)$ & (5) & (6) & $(7)$ & $(8)$ \\
\hline & \multicolumn{4}{|c|}{ Excess value } & \multicolumn{4}{|c|}{ Tobin’s Q } \\
\hline Log (total assets) & $\begin{array}{c}0.006 \\
(0.004)\end{array}$ & & $\begin{array}{c}0.006 \\
(0.004)\end{array}$ & & $\begin{array}{c}0.005 \\
(0.004)\end{array}$ & & $\begin{array}{c}0.005 \\
(0.004)\end{array}$ & \\
\hline Log(total operating income) & & $\begin{array}{c}0.011^{* * * *} \\
(0.004)\end{array}$ & & $\begin{array}{c}0.011^{* * * *} \\
(0.004)\end{array}$ & & $\begin{array}{c}0.011^{* * *} \\
(0.003)\end{array}$ & & $\begin{array}{c}0.011^{* * *} \\
(0.003)\end{array}$ \\
\hline $\begin{array}{l}\text { Net interest income to } \\
\text { total operating income }\end{array}$ & & & & & $\begin{array}{l}-0.220^{* * *} \\
(0.061)\end{array}$ & $\begin{array}{c}-0.201 * * * \\
(0.060)\end{array}$ & $\begin{array}{l}-0.221^{* * *} \\
(0.062)\end{array}$ & $\begin{array}{c}-0.202 * * * \\
(0.060)\end{array}$ \\
\hline Income diversity & $\begin{array}{c}-0.077 * * \\
(0.032)\end{array}$ & $\begin{array}{c}-0.091 * * * \\
(0.034)\end{array}$ & $\begin{array}{c}-0.076 * * \\
(0.032)\end{array}$ & $\begin{array}{c}-0.090 * * * \\
(0.034)\end{array}$ & $\begin{array}{l}-0.080^{*} \\
(0.041)\end{array}$ & $\begin{array}{c}-0.090 * * \\
(0.041)\end{array}$ & $\begin{array}{l}-0.080^{*} \\
(0.042)\end{array}$ & $\begin{array}{c}-0.090^{* *} \\
(0.041)\end{array}$ \\
\hline Deposits/Liabilities & $\begin{array}{c}0.093 * * \\
(0.041)\end{array}$ & $\begin{array}{c}0.119 * * * \\
(0.042)\end{array}$ & $\begin{array}{c}0.094 * * \\
(0.041)\end{array}$ & $\begin{array}{c}0.120 * * * \\
(0.042)\end{array}$ & $\begin{array}{c}0.094 \\
(0.059)\end{array}$ & $\begin{array}{c}0.112 * * \\
(0.057)\end{array}$ & $\begin{array}{c}0.094 \\
(0.059)\end{array}$ & $\begin{array}{c}0.113 * * \\
(0.057)\end{array}$ \\
\hline Equity/Assets & $\begin{array}{c}0.163 \\
(0.135)\end{array}$ & $\begin{array}{c}0.172 \\
(0.132)\end{array}$ & $\begin{array}{c}0.164 \\
(0.135)\end{array}$ & $\begin{array}{c}0.173 \\
(0.132)\end{array}$ & $\begin{array}{c}0.123 \\
(0.127)\end{array}$ & $\begin{array}{c}0.144 \\
(0.124)\end{array}$ & $\begin{array}{c}0.124 \\
(0.127)\end{array}$ & $\begin{array}{c}0.145 \\
(0.124)\end{array}$ \\
\hline Growth in assets & $\begin{array}{l}0.052 * * \\
(0.024)\end{array}$ & $\begin{array}{l}0.055^{* *} \\
(0.024)\end{array}$ & $\begin{array}{l}0.054 * * \\
(0.024)\end{array}$ & $\begin{array}{l}0.057 * * \\
(0.024)\end{array}$ & $\begin{array}{l}0.059 * * \\
(0.026)\end{array}$ & $\begin{array}{l}0.062 * * \\
(0.026)\end{array}$ & $\begin{array}{l}0.060 * * \\
(0.027)\end{array}$ & $\begin{array}{l}0.063 * * \\
(0.027)\end{array}$ \\
\hline Growth in income & $\begin{array}{c}0.021 \\
(0.026)\end{array}$ & $\begin{array}{c}0.019 \\
(0.026)\end{array}$ & $\begin{array}{c}0.019 \\
(0.027)\end{array}$ & $\begin{array}{c}0.017 \\
(0.027)\end{array}$ & $\begin{array}{c}0.015 \\
(0.027)\end{array}$ & $\begin{array}{c}0.013 \\
(0.027)\end{array}$ & $\begin{array}{c}0.016 \\
(0.027)\end{array}$ & $\begin{array}{c}0.014 \\
(0.027)\end{array}$ \\
\hline Market share of deposits & $\begin{array}{l}-0.010 \\
(0.085)\end{array}$ & $\begin{array}{l}-0.072 \\
(0.089)\end{array}$ & $\begin{array}{l}-0.011 \\
(0.086)\end{array}$ & $\begin{array}{l}-0.073 \\
(0.089)\end{array}$ & $\begin{array}{l}-0.007 \\
(0.085)\end{array}$ & $\begin{array}{l}-0.078 \\
(0.086)\end{array}$ & $\begin{array}{l}-0.006 \\
(0.085)\end{array}$ & $\begin{array}{l}-0.077 \\
(0.086)\end{array}$ \\
\hline GDP per capita growth & & & $\begin{array}{l}0.003^{*} \\
(0.002)\end{array}$ & $\begin{array}{l}0.003^{*} \\
(0.002)\end{array}$ & & & $\begin{array}{c}0.003 \\
(0.002)\end{array}$ & $\begin{array}{c}0.003 \\
(0.002)\end{array}$ \\
\hline Inflation & & & $\begin{array}{l}0.004 * \\
(0.002)\end{array}$ & $\begin{array}{l}0.004^{*} \\
(0.002)\end{array}$ & & & $\begin{array}{c}0.000 \\
(0.002)\end{array}$ & $\begin{array}{c}0.000 \\
(0.002)\end{array}$ \\
\hline Observations & 2773 & 2773 & 2773 & 2773 & 2773 & 2773 & 2773 & 2773 \\
\hline R-squared & 0.20 & 0.20 & 0.20 & 0.20 & 0.21 & 0.22 & 0.21 & 0.22 \\
\hline
\end{tabular}


Panel B: Asset diversity

\begin{tabular}{|c|c|c|c|c|c|c|c|c|}
\hline & $(1)$ & $(2)$ & (3) & (4) & (5) & (6) & $(7)$ & (8) \\
\hline & \multicolumn{4}{|c|}{ Excess value } & \multicolumn{4}{|c|}{ Tobin’s Q } \\
\hline Log (total assets) & $\begin{array}{c}0.005 \\
(0.004)\end{array}$ & & $\begin{array}{c}0.005 \\
(0.004)\end{array}$ & & $\begin{array}{l}0.006 * \\
(0.003)\end{array}$ & & $\begin{array}{c}0.006^{*} \\
(0.003)\end{array}$ & \\
\hline Log(total operating income) & & $\begin{array}{c}0.013 * * * \\
(0.003)\end{array}$ & & $\begin{array}{c}0.013^{* * *} \\
(0.003)\end{array}$ & & $\begin{array}{c}0.013^{* * *} \\
(0.003)\end{array}$ & & $\begin{array}{c}0.014^{* * *} \\
(0.003)\end{array}$ \\
\hline Loans to total earning assets & & & & & $\begin{array}{c}-0.177 * * \\
(0.078)\end{array}$ & $\begin{array}{c}-0.171^{* *} \\
(0.077)\end{array}$ & $\begin{array}{c}-0.177 * * \\
(0.078)\end{array}$ & $\begin{array}{c}-0.172^{* *} \\
(0.077)\end{array}$ \\
\hline Asset diversity & $\begin{array}{c}-0.141 * * * \\
(0.026)\end{array}$ & $\begin{array}{c}-0.141 * * * \\
(0.026)\end{array}$ & $\begin{array}{c}-0.142 * * * \\
(0.026)\end{array}$ & $\begin{array}{c}-0.142 * * * \\
(0.026)\end{array}$ & $\begin{array}{c}-0.110 * * \\
(0.046)\end{array}$ & $\begin{array}{c}-0.109 * * \\
(0.046)\end{array}$ & $\begin{array}{c}-0.111^{* *} \\
(0.046)\end{array}$ & $\begin{array}{c}-0.110 * * \\
(0.046)\end{array}$ \\
\hline Deposits/Liabilities & $\begin{array}{l}0.074^{*} \\
(0.039)\end{array}$ & $\begin{array}{c}0.109 * * * \\
(0.039)\end{array}$ & $\begin{array}{l}0.076^{*} \\
(0.039)\end{array}$ & $\begin{array}{c}0.110^{* * *} \\
(0.039)\end{array}$ & $\begin{array}{c}0.036 \\
(0.051)\end{array}$ & $\begin{array}{c}0.070 \\
(0.051)\end{array}$ & $\begin{array}{c}0.037 \\
(0.051)\end{array}$ & $\begin{array}{c}0.071 \\
(0.051)\end{array}$ \\
\hline Equity/Assets & $\begin{array}{c}0.136 \\
(0.132)\end{array}$ & $\begin{array}{c}0.167 \\
(0.126)\end{array}$ & $\begin{array}{c}0.138 \\
(0.131)\end{array}$ & $\begin{array}{c}0.168 \\
(0.126)\end{array}$ & $\begin{array}{c}0.158 \\
(0.122)\end{array}$ & $\begin{array}{c}0.191 \\
(0.119)\end{array}$ & $\begin{array}{c}0.159 \\
(0.122)\end{array}$ & $\begin{array}{c}0.192 \\
(0.119)\end{array}$ \\
\hline Growth in assets & $\begin{array}{c}0.027 \\
(0.022)\end{array}$ & $\begin{array}{c}0.031 \\
(0.023)\end{array}$ & $\begin{array}{c}0.030 \\
(0.023)\end{array}$ & $\begin{array}{c}0.034 \\
(0.023)\end{array}$ & $\begin{array}{c}0.042 \\
(0.027)\end{array}$ & $\begin{array}{l}0.047^{*} \\
(0.027)\end{array}$ & $\begin{array}{c}0.043 \\
(0.027)\end{array}$ & $\begin{array}{l}0.048 * \\
(0.027)\end{array}$ \\
\hline Growth in income & $\begin{array}{c}0.024 \\
(0.026)\end{array}$ & $\begin{array}{c}0.022 \\
(0.025)\end{array}$ & $\begin{array}{c}0.021 \\
(0.026)\end{array}$ & $\begin{array}{c}0.019 \\
(0.026)\end{array}$ & $\begin{array}{c}0.023 \\
(0.027)\end{array}$ & $\begin{array}{c}0.021 \\
(0.027)\end{array}$ & $\begin{array}{c}0.023 \\
(0.027)\end{array}$ & $\begin{array}{c}0.021 \\
(0.027)\end{array}$ \\
\hline Market share of deposits & $\begin{array}{l}-0.027 \\
(0.086)\end{array}$ & $\begin{array}{c}-0.130 \\
(0.091)\end{array}$ & $\begin{array}{c}-0.029 \\
(0.086)\end{array}$ & $\begin{array}{c}-0.130 \\
(0.091)\end{array}$ & $\begin{array}{c}-0.024 \\
(0.082)\end{array}$ & $\begin{array}{c}-0.127 \\
(0.086)\end{array}$ & $\begin{array}{c}-0.023 \\
(0.082)\end{array}$ & $\begin{array}{c}-0.126 \\
(0.086)\end{array}$ \\
\hline GDP per capita growth & & & $\begin{array}{c}0.005^{* *} \\
(0.002)\end{array}$ & $\begin{array}{c}0.005^{* *} \\
(0.002)\end{array}$ & & & $\begin{array}{l}0.003^{*} \\
(0.002)\end{array}$ & $\begin{array}{l}0.004 * \\
(0.002)\end{array}$ \\
\hline Inflation & & & $\begin{array}{c}0.005 * * \\
(0.002)\end{array}$ & $\begin{array}{c}0.005^{* *} \\
(0.002)\end{array}$ & & & $\begin{array}{c}0.001 \\
(0.002)\end{array}$ & $\begin{array}{c}0.001 \\
(0.002)\end{array}$ \\
\hline Observations & 2773 & 2773 & 2773 & 2773 & 2773 & 2773 & 2773 & 2773 \\
\hline R-squared & 0.29 & 0.29 & 0.29 & 0.30 & 0.20 & 0.21 & 0.20 & 0.21 \\
\hline
\end{tabular}




\section{Table 5}

\section{Diversity and Excess Value: Controlling for Endogeneity}

The dependent variable in panel $\mathrm{A}$ is the difference between actual q and activity-adjusted q (excess value) based on income diversity. The dependent variable in panel B is the difference between actual q and activity-adjusted q (excess value) based on asset diversity. The regression in column (1) is estimated with OLS and includes bank-fixed effects and year effects. The regression in column (2) is estimated using instrumental variables (IV). We use the index of restrictions on bank activities in the country from Barth et al. (2001) as instrument for income (asset) diversity. The IV regression in column (3) uses the fraction of bank applications denied in the country from Barth et al. (2001) as instrument for income (asset) diversity. The IV regression in column (4) uses the average income (asset)

diversity of other banks in the country as instrument for income (asset) diversity. The IV regression in column (5) uses the following variables as instruments for the income (asset) diversity measure: the log of total assets, return on assets, share of diversified banks, S\&P financial index, and listed on NYSE. Return on assets is pre-tax income over total assets. Share of diversified firms is the fraction of diversified banks in the country, calculated as the fraction of banks for which Diversified bank takes value of one. S\&P financial index is a dummy variable that takes value one if the company is included in the Standard and Poor's global financial index. Listed on NYSE is a dummy variable that takes value of one if the company is listed on the New York stock exchange. The self-selection model in column (6) is estimated using Heckman (1979)'s two-step procedure. The selection variable in the first-stage regression is Diversified bank, which is a dummy variable that takes value of 1 if net interest income is between $10 \%$ and $90 \%$ of total income (panel A) or if net loans is between $10 \%$ and $90 \%$ of total earning assets (panel B). The self-selection regression includes the following control variables: the log of total assets, return on assets, share of diversified banks, S\&P financial index, and listed on NYSE (not reported). Lambda is the self-selection parameter. For the IV regression in column (2)3 and (3), we also report the coefficient estimates for the instrumental variables of the first-stage regression. The F-test of instruments reports the p-value of the F-test of joint significance of identifying instruments. We also report the p-value of the Hausman specification error test which compares the difference between the IV and OLS estimators. Year dummies are included in all regressions; country dummies are included in the regressions in columns (5) to (6) (not reported). Standard errors in columns (2) to (5) are adjusted for clustering at the bank-level. Data for the years 1998-2002. * significant at 10\%; ** significant at 5\%; *** significant at $1 \%$.

Panel A: Income diversity

\begin{tabular}{|c|c|c|c|c|c|c|}
\hline & $\begin{array}{c}(1) \\
\text { OLS: Fixed effects }\end{array}$ & $\begin{array}{c}\text { (2) } \\
\text { IV: Activity restrictions }\end{array}$ & $\begin{array}{c}\text { (3) } \\
\text { IV: Entry denied }\end{array}$ & $\begin{array}{c}\text { (4) } \\
\text { IV: Diversity others }\end{array}$ & $\begin{array}{c}\text { (5) } \\
\text { IV: Multiple }\end{array}$ & $\begin{array}{c}(6) \\
\text { Self-selection }\end{array}$ \\
\hline Income diversity & $\begin{array}{c}-0.095 * * * \\
(0.015)\end{array}$ & $\begin{array}{c}-0.188 * * * \\
(0.051)\end{array}$ & $\begin{array}{c}-0.326 * * * \\
(0.082)\end{array}$ & $\begin{array}{c}-0.107^{*} \\
(0.064)\end{array}$ & $\begin{array}{c}-0.217 * * \\
(0.104)\end{array}$ & $\begin{array}{c}-0.086 * * * \\
(0.012)\end{array}$ \\
\hline Lambda & & & & & & $\begin{array}{l}-0.074 \\
(0.054)\end{array}$ \\
\hline \multicolumn{7}{|l|}{ First-stage: } \\
\hline$\overline{\text { Instrumental variable }}$ & & $\begin{array}{c}-0.068^{* * *} \\
(0.004)\end{array}$ & $\begin{array}{c}0.148 * * * \\
(0.025)\end{array}$ & & & \\
\hline Country fixed effects & No & No & No & No & Yes & Yes \\
\hline F-test of instruments (p-value) & & 0.00 & 0.00 & 0.00 & 0.00 & \\
\hline Hausman test (p-value) & & 0.08 & 0.00 & 0.97 & 0.00 & \\
\hline Observations & 3415 & 3261 & 3165 & 3400 & 3414 & 3414 \\
\hline R-squared & 0.13 & & & & & \\
\hline
\end{tabular}


Panel B: Asset diversity

(1)

$$
\text { (1) }
$$

OLS: Fixed effects IV: Activity restrictions $-0.115^{* * *}$

(0.018)

$-0.564^{* *}$

(0.263)

(3)

(4)

$\mathrm{V}$ : Entry denied

Multiple

(6)

Asset diversity

Lambda

$-0.185^{* * *}$

(0.056)

$-0.249^{* *}$

Self-selection

First-stage:

Instrumental variable

$\begin{array}{cc}-0.015^{* * *} & 0.092^{* * *} \\ (0.004) & (0.028)\end{array}$

Country fixed effects

F-test of instruments (p-value)

Hausman test (p-value)

No

0.00

0.05

Observations

3261

No
0.00
0.00
3165

No

0.00

0.17

3400

Yes

0.00

0.02

3415

3165

3414

Yes

3414 
Table 6 Scale and Scope of Activities of Specialized and Diversified Banks

The dependent variable in column (1) is the logarithm of total assets. The dependent variable in column (2) is the logarithm of net loans. The dependent variable in column (3) is the logarithm of total other earning assets. The dependent variable in column (4) is the logarithm of total operating income. The dependent variable in column (5) is the logarithm of total net interest income. The dependent variable in column (6) is the logarithm of total non-interest income. Specialized commercial bank is a dummy variable that takes value of one if net interest income is more than $90 \%$ of total income (panel A) or if net loans is more than $90 \%$ of total earning assets (panel B), and zero otherwise. Specialized investment bank is a dummy variable that takes value of one if non-interest income is more than $90 \%$ of total income (panel A), or if other earning (non-loan) assets is more than 90\% of total earning assets (panel B). The default category is Diversified bank, which is a dummy variable that takes value of one if net interest income is between $10 \%$ and $90 \%$ of total income (panel A) or if net loans is between $10 \%$ and $90 \%$ of total earning assets (panel B), and zero otherwise. All regressions include country dummies and year dummies (not reported). Standard errors are adjusted for clustering at the bank-level. Data for the years 1998-2002. * significant at 10\%; ** significant at 5\%; *** significant at 1\%.

\section{Panel A: Income diversity}

\begin{tabular}{|c|c|c|c|c|c|c|}
\hline & $\begin{array}{c}(1) \\
\text { Total assets }\end{array}$ & $\begin{array}{c}(2) \\
\text { Net loans }\end{array}$ & $\begin{array}{c}\text { (3) } \\
\text { Other earning assets }\end{array}$ & $\begin{array}{c}(4) \\
\text { Operating income }\end{array}$ & $\begin{array}{c}\text { (5) } \\
\text { Net interest income }\end{array}$ & $\begin{array}{c}(6) \\
\text { Non-interest income }\end{array}$ \\
\hline Specialized commercial bank & $\begin{array}{c}-0.989 * * * \\
(0.154)\end{array}$ & $\begin{array}{c}-0.941^{* * *} \\
(0.158)\end{array}$ & $\begin{array}{c}-0.959 * * * \\
(0.173)\end{array}$ & $\begin{array}{c}-1.224^{* * *} \\
(0.152)\end{array}$ & $\begin{array}{c}-0.897 * * * \\
(0.147)\end{array}$ & $\begin{array}{c}-2.647 * * * \\
(0.172)\end{array}$ \\
\hline Specialized investment bank & $\begin{array}{c}-0.945^{* *} \\
(0.429)\end{array}$ & $\begin{array}{c}-2.454 * * * \\
(0.372)\end{array}$ & $\begin{array}{l}-0.562 \\
(0.475)\end{array}$ & $\begin{array}{c}0.495 \\
(0.353)\end{array}$ & $\begin{array}{c}-2.178 * * * \\
(0.392)\end{array}$ & $\begin{array}{c}1.628 * * * \\
(0.371)\end{array}$ \\
\hline $\begin{array}{l}\text { Observations } \\
\text { R-squared }\end{array}$ & $\begin{array}{c}3415 \\
0.29 \\
\end{array}$ & $\begin{array}{c}3412 \\
0.30 \\
\end{array}$ & $\begin{array}{c}3415 \\
0.29 \\
\end{array}$ & $\begin{array}{c}3415 \\
0.25 \\
\end{array}$ & $\begin{array}{c}3415 \\
0.25 \\
\end{array}$ & $\begin{array}{l}3415 \\
0.32 \\
\end{array}$ \\
\hline \multicolumn{7}{|l|}{ Panel B: Asset diversity } \\
\hline & $\begin{array}{c}\text { (1) } \\
\text { Total assets }\end{array}$ & $\begin{array}{c}(2) \\
\text { Net loans } \\
\end{array}$ & $\begin{array}{c}(3) \\
\text { Other earning assets }\end{array}$ & $\begin{array}{c}(4) \\
\text { Operating income }\end{array}$ & $\begin{array}{c}\text { (5) } \\
\text { Net interest income } \\
\end{array}$ & $\begin{array}{c}\text { (6) } \\
\text { Non-interest income }\end{array}$ \\
\hline Specialized commercial bank & $\begin{array}{c}-0.683^{* *} \\
(0.328)\end{array}$ & $\begin{array}{l}-0.264 \\
(0.328)\end{array}$ & $\begin{array}{c}-2.078^{* * *} \\
(0.343)\end{array}$ & $\begin{array}{l}-0.600^{*} \\
(0.354)\end{array}$ & $\begin{array}{l}-0.440 \\
(0.331)\end{array}$ & $\begin{array}{c}-0.719 * \\
(0.419)\end{array}$ \\
\hline Specialized investment bank & $\begin{array}{l}-0.373 \\
(0.547)\end{array}$ & $\begin{array}{c}-3.453^{* * *} \\
(0.679)\end{array}$ & $\begin{array}{c}0.518 \\
(0.580)\end{array}$ & $\begin{array}{l}-0.112 \\
(0.512)\end{array}$ & $\begin{array}{c}-1.415^{* * *} \\
(0.486)\end{array}$ & $\begin{array}{c}0.749 \\
(0.573)\end{array}$ \\
\hline Observations & 3415 & 3412 & 3415 & 3415 & 3415 & 3415 \\
\hline R-squared & 0.29 & 0.30 & 0.29 & 0.25 & 0.25 & 0.32 \\
\hline
\end{tabular}


The dependent variable in columns (1), (3), and (5) is the difference between actual q and activity-adjusted q (excess value) based on income diversity. The dependent variable in columns (2), (4), and (6) is the difference between actual q and activity-adjusted q (excess value) based on asset diversity. In panel A, we exclude banks that have merged with at least one other financial institution during the current year (columns 1-2), the past 3 years (columns 3-4), or the past 5 years (columns 5-6). In panel B, we include merger dummy variables. Merger [t] is a dummy variable that takes value of one if the bank that merged with at least one other financial institution during year t. Merger [t-2, t] is a dummy variable that takes value of one if the bank that merged with at least one other financial institution during the years t-2 to t. Merger [t-4, t] is a dummy variable that takes value of one if the bank that merged with at least one other financial institution during the years t-4 to t. We define a merger as an acquisition or merger between two financial institutions where the new entity takes on a new name. This variable is constructed using data on the history of the bank from Bankscope and the mergers and acquisitions database from the Banker's Almanac. In panel C, we exclude bank observations with a significant annual change in total assets. Specifically, if a bank experienced a change in assets of more than $50 \%$ from year $t-1$ to year $t$, then we exclude the bank for the years $t, t+1, t+2, \ldots \mathrm{T}$, with $\mathrm{T}$ the end of the sample period. We include country dummies and year dummies (not reported). Standard errors are adjusted for clustering at the bank-level. Data are for the years 1998-2002. * significant at $10 \%$; ** significant at 5\%; *** significant at $1 \%$.

Panel A: Exclude banks that merged with another financial institution

\begin{tabular}{|c|c|c|c|c|c|c|}
\hline & $\begin{array}{c}(1) \\
\text { Merger [t] }\end{array}$ & $\begin{array}{c}(2) \\
\text { Merger [t] }\end{array}$ & $\begin{array}{c}(3) \\
\text { Merger [t-2, t] }\end{array}$ & $\begin{array}{c}(4) \\
\text { Merger [t-2, } t]\end{array}$ & $\begin{array}{c}(5) \\
\text { Merger }[t-4, t]\end{array}$ & $\begin{array}{c}(5) \\
\text { Merger }[\mathrm{t}-4, \mathrm{t}]\end{array}$ \\
\hline Log (total assets) & $\begin{array}{c}-0.001 \\
(0.003)\end{array}$ & $\begin{array}{l}-0.003 \\
(0.004)\end{array}$ & $\begin{array}{c}-0.001 \\
(0.003)\end{array}$ & $\begin{array}{c}-0.002 \\
(0.004)\end{array}$ & $\begin{array}{c}-0.001 \\
(0.003)\end{array}$ & $\begin{array}{c}-0.002 \\
(0.005)\end{array}$ \\
\hline Income diversity & $\begin{array}{c}-0.102 * * \\
(0.042)\end{array}$ & & $\begin{array}{c}-0.110^{* *} \\
(0.044)\end{array}$ & & $\begin{array}{c}-0.113^{* *} \\
(0.045)\end{array}$ & \\
\hline Asset diversity & & $\begin{array}{c}-0.123 * * * \\
(0.038)\end{array}$ & & $\begin{array}{c}-0.122 * * * \\
(0.039)\end{array}$ & & $\begin{array}{c}-0.122 * * * \\
(0.040)\end{array}$ \\
\hline Observations & 3362 & 3362 & 3269 & 3269 & 3222 & 3222 \\
\hline R-squared & 0.15 & 0.22 & 0.15 & 0.21 & 0.15 & 0.21 \\
\hline
\end{tabular}


Panel B: Control for banks that merged with another financial institution

\begin{tabular}{|c|c|c|c|c|c|c|}
\hline & $\begin{array}{c}(1) \\
\text { Merger [t] }\end{array}$ & $\begin{array}{c}(2) \\
\text { Merger [t] }\end{array}$ & $\begin{array}{c}(3) \\
\text { Merger }[t-2, t]\end{array}$ & $\begin{array}{c}(4) \\
\text { Merger }[t-2, t]\end{array}$ & $\begin{array}{c}(5) \\
\text { Merger }[t-4, t]\end{array}$ & $\begin{array}{c}(6) \\
\text { Merger }[t-4, t]\end{array}$ \\
\hline Log (total assets) & $\begin{array}{c}-0.002 \\
(0.003)\end{array}$ & $\begin{array}{l}-0.003 \\
(0.004)\end{array}$ & $\begin{array}{c}-0.001 \\
(0.003)\end{array}$ & $\begin{array}{l}-0.003 \\
(0.004)\end{array}$ & $\begin{array}{c}-0.001 \\
(0.003)\end{array}$ & $\begin{array}{c}-0.003 \\
(0.004)\end{array}$ \\
\hline Income diversity & $\begin{array}{c}-0.098 * * \\
(0.042)\end{array}$ & & $\begin{array}{c}-0.098 * * \\
(0.042)\end{array}$ & & $\begin{array}{c}-0.099 * * \\
(0.042)\end{array}$ & \\
\hline Asset diversity & & $\begin{array}{c}-0.127 * * * \\
(0.037)\end{array}$ & & $\begin{array}{c}-0.127 * * * \\
(0.037)\end{array}$ & & $\begin{array}{c}-0.127 * * * \\
(0.037)\end{array}$ \\
\hline Merger [t] & $\begin{array}{l}-0.007 \\
(0.025)\end{array}$ & $\begin{array}{c}0.008 \\
(0.026)\end{array}$ & & & & \\
\hline Merger [t, t-2] & & & $\begin{array}{l}-0.018 \\
(0.019)\end{array}$ & $\begin{array}{c}0.001 \\
(0.019)\end{array}$ & & \\
\hline Merger [t, t-4] & & & & & $\begin{array}{c}-0.019 \\
(0.017)\end{array}$ & $\begin{array}{c}-0.003 \\
(0.017)\end{array}$ \\
\hline Observations & 3414 & 3414 & 3414 & 3414 & 3414 & 3414 \\
\hline R-squared & 0.15 & 0.21 & 0.15 & 0.21 & 0.15 & 0.21 \\
\hline
\end{tabular}

Panel C: Exclude banks with a significant annual change in total assets

\begin{tabular}{lcc} 
& $(1)$ & $(2)$ \\
& $\begin{array}{c}\text { Significant change } \\
\text { in total assets }\end{array}$ & $\begin{array}{c}\text { Significant change } \\
\text { in total assets }\end{array}$ \\
\hline Log (total assets) & -0.002 & -0.003 \\
& $(0.003)$ & $(0.004)$ \\
Income diversity & $-0.093^{* *}$ & \\
Asset diversity & $(0.046)$ & $-0.125^{* * *}$ \\
& & $(0.041)$ \\
Observations & & 3225 \\
R-squared & 3225 & 0.22 \\
\hline
\end{tabular}


The dependent variable in columns (1) and (2) is the difference between actual q and activity-adjusted q (excess value) based on income diversity. The dependent variable in columns (3) and (4) is the difference between actual q and activity-adjusted q (excess value) based on asset diversity. The regressions in columns (1) and (3) exclude banks with major insurance operations as identified by Worldscope. These are financial institutions that are classified by Bankscope as banks but by Worldscope as insurance companies. Each of these firms reports a financial statement for insurance companies in Worldscope, and all have significant premium income. Insurance activity is a dummy variable that takes value one if the bank has major insurance operations, and zero otherwise. These are financial institutions that are classified by Bankscope as banks but by Worldscope as insurance companies (and report a financial statement for insurance companies in Worldscope). The dependent variable in column (5) is the difference between actual q and activity-adjusted q (excess value) based on income diversity, where we consider three sources of operating income: interest income, premium income, and other non-interest income. We use the global sample of banks without major insurance operations to calculate the average q of single-activity banks, and we use the global sample of insurance companies in Worldscope that are not included as banks in Bankscope to calculate the average q of stand-alone insurance companies. Excess value is calculated as follows: (Net Interest income/Total operating income)*Average q of pure commercial banks + (Net premium income minus net claims/Total operating income) *Average q of pure insurance companies) + (Other income/Total operating income) *Average q of pure investment banks. The income diversity with insurance variable is calculated similar to the income diversity variable but now considers three rather than two sources of income: interest income, premium income and other non-interest income. The variable is constructed such that 0 denotes no diversity (one source of income) and 1 denotes high diversity (all three sources have equal share in total income). The variable is calculated as follows: For banks without insurance activities: 1 - |(Net interest income-Other income)/Total operating income|. For banks with insurance activities: 1 - |Net Interest income/Total operating income - (1/3)| - |Net premium income minus net claims/Total operating income - (1/3)| - |Other income/Total operating income - (1/3)|.We include country dummies and year dummies (not reported). Standard errors are adjusted for clustering at the bank-level. Data are for the years $1998-2002 .{ }^{*}$ significant at $10 \%$; ** significant at $5 \%$; $* * *$ significant at $1 \%$.

\begin{tabular}{|c|c|c|c|c|c|}
\hline & $\begin{array}{c}(1) \\
\text { Income diversity } \\
\text { Excluding insurance } \\
\text { companies }\end{array}$ & $\begin{array}{c}\text { (2) } \\
\text { Income diversity } \\
\text { Controlling for } \\
\text { insurance companies }\end{array}$ & $\begin{array}{c}\text { (3) } \\
\text { Asset diversity } \\
\text { Excluding insurance } \\
\text { companies }\end{array}$ & $\begin{array}{c}\text { (4) } \\
\text { Asset diversity } \\
\text { Controlling for } \\
\text { insurance companies }\end{array}$ & $\begin{array}{c}\text { (5) } \\
\text { Income diversity } \\
\text { Income from insurance } \\
\text { activities }\end{array}$ \\
\hline Log (total assets) & $\begin{array}{l}-0.002 \\
(0.003)\end{array}$ & $\begin{array}{l}-0.002 \\
(0.003)\end{array}$ & $\begin{array}{l}-0.003 \\
(0.004)\end{array}$ & $\begin{array}{l}-0.003 \\
(0.004)\end{array}$ & $\begin{array}{l}-0.002 \\
(0.003)\end{array}$ \\
\hline Income diversity & $\begin{array}{c}-0.100 * * \\
(0.042)\end{array}$ & $\begin{array}{c}-0.098 * * \\
(0.042)\end{array}$ & & & \\
\hline Asset diversity & & & $\begin{array}{c}-0.127 * * * \\
(0.037)\end{array}$ & $\begin{array}{c}-0.127 * * * \\
(0.037)\end{array}$ & \\
\hline Insurance activity & & $\begin{array}{l}-0.036 \\
(0.030)\end{array}$ & & $\begin{array}{l}-0.007 \\
(0.023)\end{array}$ & \\
\hline Income diversity with insurance & & & & & $\begin{array}{c}-0.101^{* *} \\
(0.042)\end{array}$ \\
\hline Observations & 3398 & 3415 & 3398 & 3415 & 3410 \\
\hline R-squared & 0.15 & 0.15 & 0.21 & 0.21 & 0.15 \\
\hline
\end{tabular}


Table 9

Diversity and Excess Value: Sub-Samples

The dependent variable in panel $\mathrm{A}$ is the difference between actual $\mathrm{q}$ and activity-adjusted q (excess value) based on income diversity. The dependent variable in panel $B$ is the difference between actual $q$ and activity-adjusted $q$ (excess value) based on asset diversity. In column (1), we restrict the sample to diversified firms only, i.e., firms for which the Income (panel A) diversity dummy or the Asset (panel B) diversity dummy takes a value of one. In column (2), we restrict the sample to commercial banks (as defined by Bankscope) only. In column (3), we exclude U.S. banks from the sample. In columns (4) and (5), we restrict the sample to U.S. banks only. The dependent variable in column (5) uses the sample of U.S. banks rather than the global sample to calculate the average q of single activity banks. Column (6) is estimated using Weighted Least Squares, with the inverse of the number of country observations as weight. We include country dummies and year dummies (not reported). Standard errors are adjusted for clustering at the bank-level. Data are for the years 1998-2002. * significant at 10\%; $* *$ significant at $5 \%$; *** significant at $1 \%$.

Panel A: Income diversity

$(1)$

(2)

(3)

(4)

Diversified banks Commercial banks

Excluding U.S.

banks

.S. banks, Global

(5)

(6)

\begin{tabular}{|c|c|c|c|c|c|c|}
\hline \multirow{2}{*}{ Log (total assets) } & & & banks & benchmark & benchmark & \\
\hline & $\begin{array}{c}0.000 \\
(0.002)\end{array}$ & $\begin{array}{c}-0.021 * * * \\
(0.004)\end{array}$ & $\begin{array}{c}-0.008^{* * *} \\
(0.003)\end{array}$ & $\begin{array}{l}0.004^{*} \\
(0.002)\end{array}$ & $\begin{array}{c}0.011^{* * *} \\
(0.002)\end{array}$ & $\begin{array}{l}0.005 * * \\
(0.002)\end{array}$ \\
\hline Income diversity & $\begin{array}{c}-0.081 * * * \\
(0.020)\end{array}$ & $\begin{array}{c}-0.184 * * * \\
(0.044)\end{array}$ & $\begin{array}{c}-0.144 * * * \\
(0.035)\end{array}$ & $\begin{array}{l}-0.030 \\
(0.020)\end{array}$ & $\begin{array}{l}-0.008 \\
(0.019)\end{array}$ & $\begin{array}{c}-0.041 * * \\
(0.016)\end{array}$ \\
\hline Observations & 3165 & 1495 & 2051 & 1364 & 1364 & 3415 \\
\hline R-squared & 0.20 & 0.24 & 0.15 & 0.05 & 0.04 & 0.12 \\
\hline
\end{tabular}

Panel B: Asset diversity

(1)

(2)

(3)

(4)

Diversified banks Commercial banks

Log (total assets)

$-0.002$

$(0.002)$

Asset diversity

$-0.132 * * *$

$-0.024^{* * *}$

(0.007)

$-0.163 * * *$

uding U.S.

U.S. banks, Global

benchmark

banks

$0.008^{* * *}$

0.12

Observations

(0.019)

(0.044)

(0.004)

$-0.087^{* *}$

(0.002)

$-0.143 * * *$

(0.037)

(0.018)

U.S. banks, U.S.

(6)

R-squared

3218

1495

0.31

2051

1364

0.19

benchmark

$0.012^{* * *}$

$0.008^{* * * *}$

(0.002)

$-0.097 * * *$

(0.002)

R-squared

$\begin{array}{lll}0.24 & 0.31 & 0.21\end{array}$

0.19

(0.017)

$-0.118 * * *$

(0.014)

3415

0.24 
The dependent variable in column (1) is the difference between actual q and activity-adjusted q (excess value) based on income diversity calculated, calculated using the median q of single-activity banks rather than the average q of single-activity banks. The dependent variable in column (2) is the difference between actual q and activity-adjusted q (excess value) based on income diversity, where we use the sample of U.S. banks rather than the global sample to calculate the average q of single activity banks. The dependent variable in column (3) is the difference between actual operating income-to-total assets and activity-adjusted operating income-to-total assets (excess income) based on income diversity, calculated using the average operating income-to-total assets ratio of single-activity banks. The dependent variable in column (4) is the difference between actual q and activity-adjusted q (excess value) based on asset diversity calculated using the median q for single-activity banks rather than the average q for single-activity banks. The dependent variable in column (5) is the difference between actual q and activity-adjusted q (excess value) based on asset diversity, where we use the sample of U.S. banks rather than the global sample to calculate the average q of single activity banks. The dependent variable in column (6) is the difference between actual operating income-to-total assets and activity-adjusted operating income-to-total assets (excess income) based on asset diversity, calculated using the average operating income-to-total assets ratio of single-activity banks. We include country dummies and year dummies (not reported). Standard errors are adjusted for clustering at the bank-level. Data are for the years 1998-2002. * significant at $10 \%$; ** significant at $5 \%$; *** significant at $1 \%$.

\begin{tabular}{|c|c|c|c|c|c|c|}
\hline & \multicolumn{2}{|c|}{ Income diversity } & (3) & (4) & $\begin{array}{l}\text { (5) } \\
\text { sset divers }\end{array}$ & (6) \\
\hline & Median & U.S. & Excess income & Median & U.S. & Excess income \\
\hline Log (total assets) & $\begin{array}{c}0.001 \\
(0.003)\end{array}$ & $\begin{array}{c}0.002 \\
(0.003)\end{array}$ & $\begin{array}{c}-0.007^{* * *} \\
(0.001)\end{array}$ & $\begin{array}{l}-0.001 \\
(0.004)\end{array}$ & $\begin{array}{l}-0.001 \\
(0.004)\end{array}$ & $\begin{array}{c}-0.004 * * * \\
(0.001)\end{array}$ \\
\hline Income diversity & $\begin{array}{c}-0.089 * * \\
(0.043)\end{array}$ & $\begin{array}{c}-0.092 * * \\
(0.043)\end{array}$ & $\begin{array}{c}-0.029 * * * \\
(0.009)\end{array}$ & & & \\
\hline Asset diversity & & & & $\begin{array}{c}-0.083^{* *} \\
(0.037)\end{array}$ & $\begin{array}{c}-0.091 * * \\
(0.037)\end{array}$ & $\begin{array}{c}-0.020 * * * \\
(0.007)\end{array}$ \\
\hline Observations & 3415 & 3415 & 3411 & 3415 & 3415 & 3410 \\
\hline R-squared & 0.12 & 0.13 & 0.42 & 0.14 & 0.23 & 0.22 \\
\hline
\end{tabular}

